\title{
Glucocorticoid metabolism and reproduction: a tale of two enzymes
}

\author{
Anthony E. Michael ${ }^{1,2}$, Lisa M. Thurston ${ }^{1,2}$ and Michael T. Rae ${ }^{3}$ \\ ${ }^{1}$ Department of Biochemistry and Molecular Biology, University College London, Rowland Hill Street, \\ London NW3 2PF, UK; ${ }^{2}$ Reproduction and Development Group, Department of Veterinary Basic \\ Sciences, Royal Veterinary College, Royal College Street, London NW1 OTU, UK; and ${ }^{3}$ Section of \\ Obstetrics and Gynaecology, Division of Reproductive and Developmental Sciences, \\ Centre for Reproductive Biology, University of Edinburgh, Chancellor's Building, \\ 49 Little France Crescent, Edinburgh EH16 4SB, UK
}

\begin{abstract}
Within potential target cells, the actions of physiological glucocorticoids (cortisol and corticosterone) are modulated by isoforms of the enzyme $11 \beta$-hydroxysteroid dehydrogenase (11ßHSD). To date, two isoforms of $11 \beta \mathrm{HSD}$ have been cloned: $11 \beta \mathrm{HSD} 1$ acts predominantly as an $\mathrm{NADP}(\mathrm{H})$-dependent reductase to generate active cortisol or corticosterone, and $11 \beta \mathrm{HSD} 2$ is a high affinity $\mathrm{NAD}^{+}$-dependent enzyme that catalyses the enzymatic inactivation of glucocorticoids. Whereas the regeneration of active glucocorticoids by $11 \beta \mathrm{HSD} 1$ has been implicated in the cellular mechanisms of pituitary function, ovulation and parturition, the enzymatic inactivation of cortisol and corticosterone by $11 \beta \mathrm{HSD}$ enzymes appears to be central to the protection of gonadal steroidogenesis, prevention of intra-uterine growth retardation, and lactation. Recent evidence indicates that follicular fluid contains endogenous modulators of cortisol metabolism by $11 \beta \mathrm{HSD} 1$, the concentrations of which are associated with the clinical outome of assisted conception cycles and are altered in cystic ovarian disease. In conclusion, the two cloned isoforms of $11 \beta \mathrm{HSD}$ fulfil diverse roles in a wide range of reproductive processes from conception to lactation.
\end{abstract}

The definitive role of glucocorticoids, synthesized in the zona fasciculata of the adrenal cortex in response to adrenocorticotrophic hormone (ACTH), is to increase plasma glucose concentrations. However, these steroids exert diverse actions throughout the body, many of which have important implications for fertility. Before excretion in the urine or faeces, glucocorticoids must be rendered water soluble by the sequential actions of hepatic $5 \alpha$ or $5 \beta$-reductase and $3 \alpha$ - or $3 \beta$-hydroxysteroid dehydrogenase $(3 \alpha \mathrm{HSD}$ or $3 \beta \mathrm{HSD})$ which reduce $\mathrm{C}=\mathrm{C}$ double bonds and ketones, respectively, to generate hydrophilic dihydro- and tetrahydro-steroid metabolites. It was recognized in the late 1950s that within potential target cells, the actions of glucocorticoids are modulated by $11 \beta$-hydroxysteroid dehydrogenases (11ßHSD) (EC 1.1.1.146) which catalyse the reversible inactivation of cortisol and corticosterone to their inert 11-ketosteroid metabolites, cortisone and 11-dehydrocorticosterone, respectively (Bush et al., 1968) (Fig. 1). Although the biochemistry of $11 \beta \mathrm{HSD}$ is well established, it is only over the past decade that studies have started to

Email: t.michael@rfc.ucl.ac.uk define the physiological significance of glucocorticoid metabolism by these enzymes. This review focuses on the emerging importance of $11 \beta \mathrm{HSD}$ isoenzymes in the germ cells, testis, ovary, reproductive tracts, placenta and mammary glands. As this field of reproductive biology is comparatively new, this review summarizes the current understanding of the physiological roles played by $11 \beta \mathrm{HSD}$ in diverse processes including reproductive suppression, ovulation, luteinization, cystic ovarian disease, the developmental potential of oocytes, intra-uterine growth retardation (IUGR), parturition and lactation. Where sufficient robust data have been published, this review summarizes the defined roles for the $11 \beta \mathrm{HSD}$ enzymes. However, this review also includes working hypotheses which fit all of the data currently available, but which will be subject to change as further experimental evidence is reported.

\section{Physiology and molecular biology of $11 \beta \mathrm{HSD}$}

Before discussing specific roles for $11 \beta \mathrm{HSD}$ in reproductive tissues, it is necessary to outline major milestones in the history of this enzyme. To date, two biochemically distinct isoforms of $11 \beta \mathrm{HSD}$, designated type $111 \beta \mathrm{HSD}$ 
Table 1. Biochemical properties of cloned isoforms of $11 \beta$-hydroxysteroid dehydrogenase (11ßHSD)

\begin{tabular}{lll}
\hline & \multicolumn{1}{c}{$11 \beta \mathrm{HSD} 1$} & \multicolumn{1}{c}{$11 \beta \mathrm{HSD} 2$} \\
\hline Gene & HSD11B1 & HSD11B2 \\
Enzyme cofactor & $\mathrm{NADPH}>\mathrm{NADP}^{+}$ & $\mathrm{NAD}^{+}$only \\
& $\left(>>>\mathrm{NADH}>\mathrm{NAD}^{+}\right)$ & \\
$K_{\mathrm{m}}-$ cortisol & $17-27 \mu \mathrm{mol} \mathrm{I}^{-1}$ & $14-60 \mathrm{nmol} \mathrm{I}^{-1}$ \\
$\left(K_{\mathrm{m}}-\right.$ corticosterone $)$ & $\left(2 \mu \mathrm{mol} \mathrm{I}^{-1}\right)$ & $\left(1-10 \mathrm{nmol} \mathrm{I}^{-1}\right)$ \\
$K_{\mathrm{m}}-$ cortisone & $300 \mathrm{nmol} \mathrm{I}^{-1}$ & $\infty$ \\
Direction of reaction & Bi-directional: 11 -ketosteroid & Uni-directional: \\
& reductase $>11 \beta$ - dehydrogenase & $11 \beta$-dehydrogenase only \\
\hline
\end{tabular}

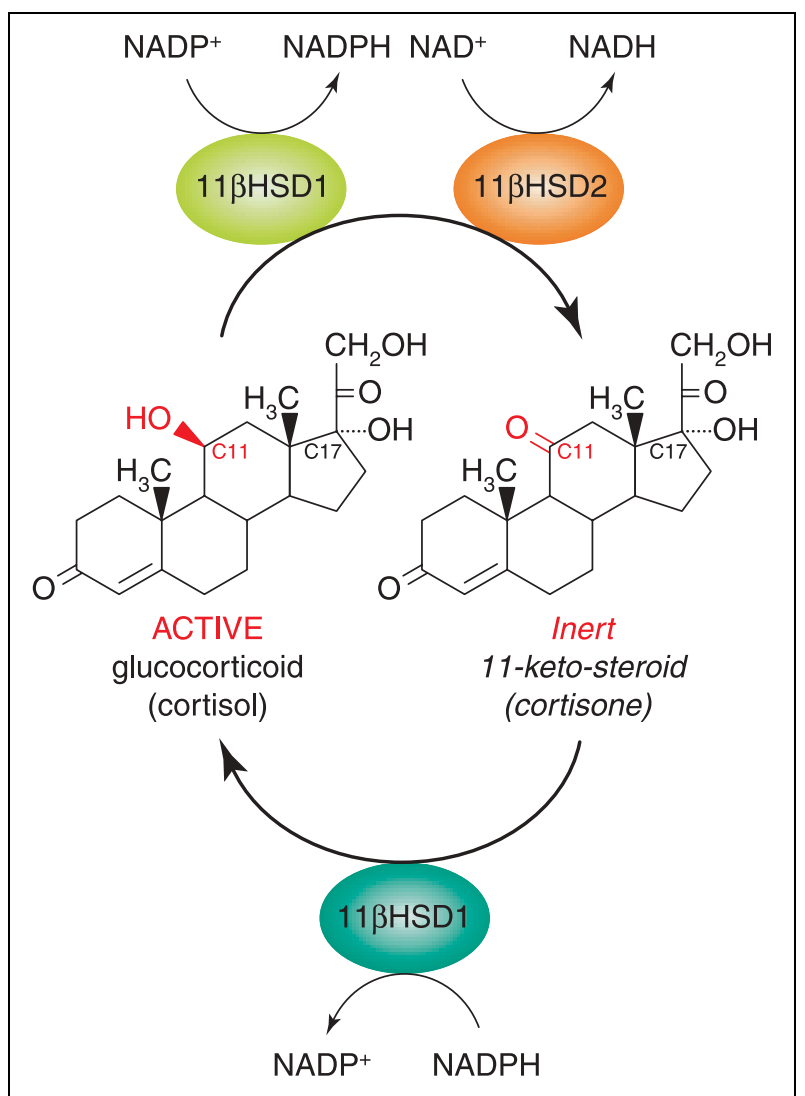

Fig. 1. Interconversion of cortisol and cortisone by enzymatic oxidation or reduction at carbon position 11 (C11), catalysed by the two cloned isoforms of $11 \beta$-hydroxysteroid dehydrogenase $(11 \beta \mathrm{HSD})$. By convention, bonds below the plane of the molecule ( $\alpha$ bonds) are represented by dotted lines; bonds which have no definitive orientation are represented by solid lines; and bonds above the plane of the molecule ( $\beta$ bonds) are represented by solid triangles. Corticosterone and 11-dehydrocorticosterone have similar structures to cortisol and cortisone, respectively, but lack the $\alpha$-hydroxyl groups at position $\mathrm{C} 17$.

(11ßHSD1) and type $211 \beta \mathrm{HSD}(11 \beta \mathrm{HSD} 2)$, have been cloned. (By convention, terms in standard upper case text refer to the enzyme proteins, $11 \beta \mathrm{HSD} 1$ and $11 \beta \mathrm{HSD} 2$, whereas the corresponding genes are referred to in italicized text, HSD11B1 and HSD11B2, respectively.)
Both cloned isoforms of $11 \beta \mathrm{HSD}$ are members of the short-chain alcohol dehydrogenase superfamily of enzymes, which includes not only other mammalian and bacterial HSD enzymes, but also 15-hydroxyprostaglandin dehydrogenase (PGDH), retinol dehydrogenase, and the hepatic alcohol dehydrogenase (Penning, 1997). Whereas the $11 \beta \mathrm{HSD}$ enzymes are closely related to other hydroxysteroid dehydrogenases, such as the $3 \beta \mathrm{HSD}, 17 \beta \mathrm{HSD}$ and $20 \alpha \mathrm{HSD}$ enzymes, $11 \beta \mathrm{HSD} 1$ and $11 \beta \mathrm{HSD} 2$ are distinct gene products (encoded by the HSD11B1 and HSD11B2 genes, respectively) which share only $14 \%$ homology in their primary sequence (Albiston et al., 1994). Although both enzymes have similar active sites, with a conserved catalytic triad comprising tyrosine, serine and lysine (Penning, 1997), 11ßHSD1 acts as a dimer or tetramer whereas $11 \beta \mathrm{HSD} 2$ appears only to be active in its monomeric form. The biochemical properties of the two cloned $11 \beta \mathrm{HSD}$ enzymes are summarized (Table 1 ). $11 \beta \mathrm{HSD} 2$ has an absolute requirement for the oxidized form of nicotinamide adenine dinucleotide $\left(\mathrm{NAD}^{+}\right)$as an enzyme cofactor, whereas $11 \beta \mathrm{HSD} 1$ preferentially utilizes nicotinamide adenine dinucleotide phosphate $\left(\mathrm{NADP}^{+} / \mathrm{NADPH}\right)$.

$11 \beta \mathrm{HSD} 1$ was originally isolated from liver (Lakshmi and Monder, 1988), where it acts as an NADPHdependent reductase to generate active glucocorticoids from inert 11-ketosteroids (Fig. 1). After cloning of 11ßHSD1 (Agarwal et al., 1989; Tannin et al., 1991), this reductive enzyme isoform was shown to be widely expressed, co-localizing with glucocorticoid receptors (Whorwood et al., 1992; Seckl and Walker, 2001). On the basis of this pattern of expression, it is generally accepted that the principal role of $11 \beta \mathrm{HSD} 1$ is to regenerate cortisol or corticosterone to maximize activation of the glucocorticoid receptors (Seckl and Walker, 2001). However, whereas $11 \beta \mathrm{HSD} 1$ acts predominantly as a ketosteroid reductase in intact cells, this enzyme is inherently bi-directional; in cell homogenates provided with $\mathrm{NADP}^{+}, 11 \beta \mathrm{HSD} 1$ can inactivate glucocorticoids, albeit with a low affinity $\left(K_{\mathrm{m}}\right.$ for cortisol $\left.=27 \mu \mathrm{mol} \mathrm{I}{ }^{-1}\right)$ (Lakshmi and Monder, 1988; Agarwal et al., 1989) (Table 1). Hence, the predominant direction of reaction catalysed by $11 \beta \mathrm{HSD} 1$ depends on the redox state of 
NADP $(H)$ in a particular cell. In liver cells, with an abundant supply of glucose (glycogen) and an active pentose phosphate pathway, most NADP will be in the reduced form, favouring the NADPH-dependent ketosteroid reductase activity of $11 \beta \mathrm{HSD} 1$. However, in the steroidogenic cells of the testis, ovary and placenta, the activity of NADPH-dependent cytochrome P450 enzymes, required for the biosynthesis of steroids, favours the oxidation of $\mathrm{NADPH}$ to $\mathrm{NADP}^{+}$, thus promoting the oxidative activity of $11 \beta \mathrm{HSD} 1$.

Failure of $11 \beta \mathrm{HSD} 1$ to act as an 11 -ketosteroid reductase in the liver manifests as 'apparent cortisone reductase deficiency' (ACRD) (Phillipou and Higgins, 1985; Jamieson et al., 1999). As ACRD has been reported to date in only five women, each diagnosed with anovulatory infertility, hyperandrogenism and polycystic ovaries, the molecular basis and reproductive consequences of this condition will be discussed later. A second clinical syndrome of defective glucocorticoid metabolism is that of 'apparent mineralocorticoid excess' (AME) (Ulick et al., 1979; Stewart et al., 1988). In this syndrome, glucocorticoids are not inactivated, due to a defect in the oxidative activity of $11 \beta \mathrm{HSD}$, and so gain access to mineralocorticoid receptors which display little inherent specificity for their normal ligand, aldosterone (Krozowski and Funder, 1983; Arriza et al., 1987). As glucocorticoids circulate at concentrations 1000-fold higher than aldosterone, the mineralocorticoid receptors are hyperstimulated, resulting in excessive sodium transport and significant changes in sodium-dependent fluid fluxes (Funder et al., 1988). Increased resorption of water in the distal nephron and colon increases blood volume and pressure, suppressing plasma renin activity and the concentration of aldosterone (Ulick et al., 1979; Stewart et al., 1988).

After the cloning of the human HSD11B1 gene, patients with the inherited form of AME were screened for mutations. The lack of any mutations in these patients (Nikkila et al., 1993), and the low affinity of $11 \beta \mathrm{HSD} 1$, implicated the existence of a second isoform of $11 \beta \mathrm{HSD}$ to protect the non-specific mineralocorticoid receptors. In 1994, 11ßHSD2 was cloned (Agarwal et al., 1994; Albiston et al., 1994) and identified as the enzymatic 'gatekeeper' that excludes glucocorticoids from mineralocorticoid receptors (Fig. 2). Unlike $11 \beta \mathrm{HSD} 1$, $11 \beta \mathrm{HSD} 2$ has been localized to mineralocorticoid target cells in the kidney, colon and parotid glands, as well as to the pancreas and placenta (Mercer and Krozowski, 1992; Brown et al., 1993; Albiston et al., 1994). With physiological substrates, $11 \beta \mathrm{HSD} 2$ acts exclusively as an $\mathrm{NAD}^{+}$-dependent, high affinity $11 \beta$-dehydrogenase $\left(K_{\mathrm{m}}\right.$ for cortisol $\left.=60 \mathrm{nmol} \mathrm{I}^{-1}\right)$ (Mercer and Krozowski, 1992; Brown et al., 1993; Albiston et al., 1994) (Table 1). Although this enzyme can catalyse limited reduction of the synthetic steroid, 11-dehydrodexamethasone, it has no reductive activity against cortisone or 11-dehydrocorticosterone, even in the presence of excess $\mathrm{NADH}$.

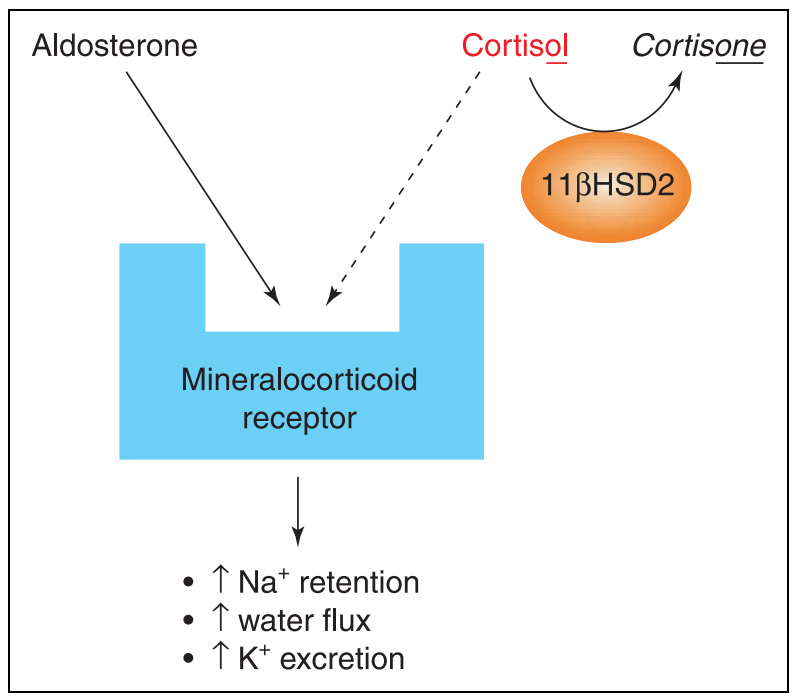

Fig. 2. Modulation of glucocorticoid access to the 'mineralocorticoid receptor' by $11 \beta$-hydroxysteroid dehydrogenase 2 (11ßHSD2), a molecular 'gatekeeper'. Deficiency of $11 \beta$ HSD2 activity allows cortisol to gain access to the promiscuous mineralocorticoid receptor.

Although patients with the inherited form of $\mathrm{AME}$ have been shown to inherit recessive mutations in the HSD11B2 gene that encodes 11ßHSD2 (Mune et al., 1995; Ferrari et al., 1996), such congenital defects are rare. By comparison, failure of $11 \beta \mathrm{HSD} 2$ due to enzyme inhibition is relatively common. Important inhibitors of $11 \beta \mathrm{HSD} 2$ include glycyrrhizic and glycyrrhetinic acids (metabolites of liquorice) (Stewart et al., 1987; Monder et al., 1989), and, particularly relevant for the current review, progesterone (Lopez-Bernal et al., 1980; Sun et al., 1998; Burton and Waddell, 2002).

\section{$11 \beta \mathrm{HSD}$ in the hypothalamus and anterior pituitary gland}

In reproductive biology, any review should logically begin at the level of the hypothalamo-pituitary complex, where both cloned isoforms of $11 \beta \mathrm{HSD}$ are known to be expressed and functional. In $11 \beta \mathrm{HSD} 1$ knockout mice, which are unable to reduce 11 -ketosteroids to active glucocorticoids, there is increased hypothalamic secretion of corticotrophin-releasing hormone $(\mathrm{CRH})$ and increased ACTH drive to the adrenal gland, indicating that $11 \beta \mathrm{HSD} 1$ is required in the hypothalamus or anterior pituitary corticotrophs for glucocorticoids to exert full negative feedback in the hypothalamo-pituitary-adrenal (HPA) axis (Harris et al., 2001). A recent study confirmed that regeneration of glucocorticoids by $11 \beta \mathrm{HSD} 1$ limits the sensitivity of corticotrophs to $\mathrm{CRH}$ by decreasing the expression of CRH receptors (Hanafusa et al., 2002). Moreover, pilot studies in the present authors' laboratory 
have found that one or more of the $11 \beta \mathrm{HSD}$ enzymes is active in $\alpha \mathrm{T} 3-1$ and L $\beta$ T2 gonadotroph cells, and that $11 \beta \mathrm{HSD}$ activities respond acutely to $\mathrm{GnRH}$ in these pituitary gonadotroph cell lines (Thurston et al., 2003a).

\section{Testicular 11 $\beta$ HSD: fertility and reproductive suppression}

Over the past three decades, it has emerged that glucocorticoids exert a number of deleterious effects on the interstitial Leydig cells of the testis, including direct inhibition of testosterone biosynthesis, suppression of $\mathrm{LH}$ receptor expression, and induction of Leydig cell apoptosis (Bambino and Hsueh, 1981; Monder et al., 1994; Gao et al., 2002). Shortly after the cloning of rat $11 \beta$ HSD1, Phillips et al. (1989) confirmed expression of this enzyme in rat Leydig cells. In subsequent studies, $11 \beta \mathrm{HSD} 1$ was shown to alleviate inhibition of testosterone biosynthesis by corticosterone (Monder et al., 1994). This protective role presumes that in rat Leydig cells, $11 \beta$ HSD1 acts predominantly as an $11 \beta$-dehydrogenase. However, this assumption was challenged by Leckie et al. (1998) who found that $11 \beta \mathrm{HSD} 1$ acts as an 11ketosteroid reductase in rat Leydig cells maintained in primary culture. Detailed in vitro studies have since revealed that the predominant direction of testicular $11 \beta \mathrm{HSD} 1$ activity depends on the age of the rat from which Leydig cells have been harvested, the duration of incubation with enzyme substrates, and the precise composition of the cell culture medium in which enzyme activities are assessed. Expression of $11 \beta \mathrm{HSD} 1$ is highest, and the reductase activity of this enzyme predominates, in immature Leydig cells (Ge et al., 1997a), on prolonged incubation with steroid substrates (Ge and Hardy, 2000), and in culture medium containing high concentrations of D-glucose or pyruvate (Ferguson et al., 1999; Ge and Hardy, 2000). However, in adult Leydig cells, on acute incubation with corticosterone $(<1 \mathrm{~h})$ or in Dulbecco's modified Eagle's medium without added glucose or pyruvate, expression of $11 \beta \mathrm{HSD} 1 \mathrm{mRNA}$ is decreased and the oxidative activity of $11 \beta \mathrm{HSD}$ predominates (Ge et al., 1997a; Ferguson et al., 1999; Ge and Hardy, 2000).

In attempting to resolve disputes over the preferred direction of action of $11 \beta \mathrm{HSD} 1$ in Leydig cells in rats, evidence has accumulated to indicate the existence of an enzyme activity that is biochemically distinct from either of the cloned isoforms of $11 \beta \mathrm{HSD}$. In addition to the low affinity, NADPH-dependent activity characteristic of $11 \beta \mathrm{HSD} 1$, Leydig cells also exhibit an NADP ${ }^{+}$ dependent enzyme activity which acts preferentially as a high affinity dehydrogenase $\left(K_{\mathrm{m}}\right.$ for corticosterone $=$ $42 \mathrm{nmol} \mathrm{I}^{-1}$ ) (Ge et al., 1997b). Available evidence indicates that this represents a novel isoform of $11 \beta \mathrm{HSD}$, rather than a post-translationally modified form of $11 \beta \mathrm{HSD} 1$.

Investigation of the hormonal regulation of $11 \beta \mathrm{HSD} 1$ in testis Leydig cells (Gao et al., 1997) established that over 3 days in primary culture, both $\mathrm{LH}$ and epidermal growth factor (EGF) upregulated expression of $11 \beta$ HSD1 mRNA. In the case of EGF, this increase in $11 \beta$ HSD1 expression was accompanied by a significant increase in 11-ketosteroid reductase activity, whereas both $\mathrm{LH}$ and EGF decreased the net $11 \beta$-dehydrogenase activity in cultured Leydig cells (Gao et al., 1997). Recent studies have revealed that increase of intracellular calcium favours testicular 11-ketosteroid reductase activity, whereas activation of protein kinase C (PKC) inhibits the net reductase activity and instead stimulates the net oxidation of glucocorticoids in rat Leydig cells (Ge and Hardy, 2002). Analysis of the primary amino acid sequences of the $11 \beta \mathrm{HSD} 1$ and $11 \beta \mathrm{HSD} 2$ proteins reveals multiple phosphorylation sequences for calmodulin kinase, casein kinase II and various tyrosine kinases. However, whereas the catalytic domain of $11 \beta \mathrm{HSD} 1$ contains a consensus phosphorylation site for PKC, there is no such sequence in $11 \beta \mathrm{HSD} 2$, and neither $11 \beta \mathrm{HSD} 1$ nor $11 \beta \mathrm{HSD} 2$ contains a consensus phosphorylation sequence for protein kinase $A$ (PKA). Given that the enzymes contain binding sites for both calcium and for adenosine triphosphate (ATP), it seems probable that in Leydig cells direct binding of calcium to $11 \beta \mathrm{HSD} 1$ stimulates the reductase activity of this enzyme, whereas phosphorylation of the active site via PKC favours the oxidative activity of this enzyme.

With respect to the physiological relevance of $11 \beta \mathrm{HSD}$ in Leydig cells, the fact that $11 \beta \mathrm{HSD} 1$ protein cannot be detected before day 31 after birth (Schafers et al., 2001), and the developmental switch from predominant reductase activity in mesenchymal-like Leydig cell progenitors to an oxidase in adult Leydig cells (Ge et al., 1997a), indicates a role for testicular 11ßHSD enzymes in increased testosterone synthesis at puberty. Moreover, latest reports indicate that failure of testicular $11 \beta \mathrm{HSD}$ to protect Leydig cells from the adverse effects of corticosterone contributes to decreased testosterone output in socially subordinate male rats whereas increased testicular $11 \beta \mathrm{HSD}$ activities are observed in dominant males (Hardy et al., 2002). As these trends mirror changes in serum $\mathrm{LH}$ concentrations within the first week of establishing the social hierarchy (Hardy et al., 2002), the authors propose that $\mathrm{LH}$ upregulates the protective $11 \beta \mathrm{HSD}$ system in sexually active dominant male rats (allowing their Leydig cells to maintain testosterone production in the face of increased plasma corticosterone), whereas suppression of LH in social subordinates contributes to the decrease in testicular $11 \beta \mathrm{HSD}$ activities.

\section{$11 \beta H S D$ in spermatozoa and the male reproductive tract}

Within testis Leydig cells, expression of $11 \beta \mathrm{HSD} 1$ protein coincides with the maturation of elongate spermatids in neighbouring seminiferous tubules (Neumann et al., 
1993). 11ßHSD activity has also been reported in spermatozoa and other cellular components of human semen (Nacharaju et al., 1997). Moreover, the net oxidative activities of $11 \beta \mathrm{HSD}$ were 10 -fold higher in semen from men with low sperm counts or a high percentage of morphologically abnormal spermatozoa compared with ejaculates with high sperm counts or good sperm morphology (Nacharaju et al., 1997). Although the physiological role for $11 \beta \mathrm{HSD}$ in spermatozoa has yet to be defined, it is relevant to note that human seminal plasma contains relatively high concentrations of cortisol (Brotherton, 1990) and that in men with increased serum cortisol concentrations (due to Cushing's disease), pathological changes occur in the seminiferous tubules (McKenna et al., 1979).

Enzyme activity was localized histochemically to the entire length of the mouse epididymis in initial studies of testicular 11ßHSD (Rastogi et al., 1976). In the epithelium of the vas deferens in pigs, glucocorticoids have been associated with increased sodium absorption (Phillips and Schultz, 2002), which would be expected to reduce seminal fluid volume, leading to a high viscosity luminal environment for the mature spermatozoa. In addition, corticosteroid-dependent sodium absorption will limit the activity of sodium-proton co-transporters in the epithelia of the male reproductive tract which participate in the control of seminal pH (Pushkin et al., 2000). Hence, alterations in $11 \beta \mathrm{HSD}$-mediated glucocorticoid metabolism within the male reproductive tract modify the luminal environment for maturing spermatozoa.

\section{$11 \beta H S D$ in the oocyte}

In a wide range of teleost species, cortisol, 11deoxycortisol and related hydroxylated metabolites of progesterone stimulate oocyte maturation and developmental potential (for example see Kime et al., 1992; Petrino et al., 1993; Pinter and Thomas, 1999). To date, investigations of the direct effects of glucocorticoids on mammalian oocytes, confined to studies of pig oocytes, have found that glucocorticoids inhibit meiotic development (Yang et al., 1999). In contrast, in follicular aspirates of women undergoing assisted conception, follicular glucocorticoid concentrations, which increase following the preovulatory LH surge (Andersen and Hornnes, 1994; Harlow et al., 1997), have been positively correlated with oocyte maturity (Fateh et al., 1989; Jimena et al., 1992).

Metabolism of glucocorticoids by $11 \beta \mathrm{HSD}$ in mammalian oocytes further implicates these steroids in mammalian oogenesis. Although $11 \beta \mathrm{HSD}$ expression has been reported in human oocytes (Ricketts et al., 1998; Smith et al., 2000), the most convincing data have been obtained in the ovary in rats, wherein expression of $11 \beta \mathrm{HSD} 1 \mathrm{mRNA}$ and protein were both very high in the oocyte (Benediktsson et al., 1992). In interpreting this observation, it is important to note that in oocytes, transcription of new mRNA is blocked between the preovulatory resumption of meiosis and the second mitotic division of the two-cell embryo. Hence, high expression of $11 \beta \mathrm{HSD} 1$ in the preovulatory oocyte could reflect roles for this reductive isoform of $11 \beta \mathrm{HSD}$ in the ovulatory oocyte, zygote or early embryo.

\section{$11 \beta H S D$ across the ovarian cycle: roles in ovulation and luteinization}

As in Leydig cells of the testis, glucocorticoids act directly on ovarian cells to inhibit both gonadotrophin action and steroid biosynthesis (Hsueh and Erickson, 1978; Michael et al., 1993). Moreover, before the cloning of $11 \beta \mathrm{HSD}$ isoforms, it was established that in granulosa lutein cells in humans, $11 \beta \mathrm{HSD}$ inactivates glucocorticoids, so increasing the concentration of cortisol required to inhibit LH-stimulated steroidogenesis by an order of magnitude (Michael et al., 1993).

Within ovarian follicles in humans, $11 \beta \mathrm{HSD} 2$ protein has been localized to theca cells with low 11ßHSD2 activity measured in theca cells isolated from immature follicles (Ricketts et al., 1998; Yong et al., 2000). As regards enzyme expression in granulosa cells, this is highly dependent on the functional phenotype and differentiation of the cells. In parallel studies of ovaries in rats and humans, Tetsuka et al. (1997, 1999a) demonstrated that granulosa cells that have not experienced an LH surge co-express mRNA encoding 11ßHSD2 and mineralocorticoid receptors. Thurston et al. (2003b) observed expression of $11 \beta \mathrm{HSD} 2$ protein in bovine follicles at all stages of development. Given the pivotal role for $11 \beta \mathrm{HSD} 2$ in regulating stimulation of sodiumdependent fluid fluxes via mineralocorticoid receptors, this implicates corticosteroids in the control of follicular fluid accumulation during the expansion of the antral follicle.

In human and rat granulosa cells which have luteinized following exposure to an ovulatory dose of $\mathrm{LH}$ in vivo, there is no detectable expression of $11 \beta \mathrm{HSD} 2$ mRNA or protein (Michael et al., 1997; Tetsuka et al., 1997, 1999a; Thurston et al., 2003c). Instead, the predominant enzyme isoform in such cells is $11 \beta \mathrm{HSD} 1$ (Michael et al., 1997; Tetsuka et al., 1997, 1999a), expression of which increases progressively as the cells undergo functional luteinization (Thurston et al., 2003c). Moreover, the only cloned isoform of $11 \beta \mathrm{HSD}$ expressed in the corpus luteum of pregnant rats (until such time as the gland undergoes functional regression) is $11 \beta \mathrm{HSD} 1$ (Waddell et al., 1996). This transition from expression of $11 \beta \mathrm{HSD} 2$ in follicular granulosa cells to $11 \beta \mathrm{HSD} 1$ in luteinized granulosa cells is accompanied by a switch in expression from mineralocorticoid receptors in the follicle to glucocorticoid receptors in luteinized cells (Tetsuka et al., 1997, 1999a) (Fig. 3).

Hillier and colleagues have determined the molecular basis for the transition from 11ßHSD2 to $11 \beta \mathrm{HSD} 1$ 


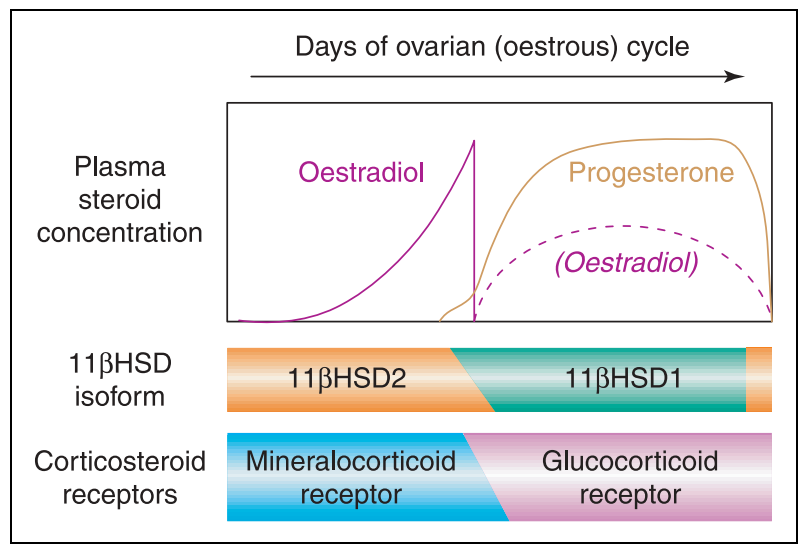

Fig. 3. Temporal pattern of expression of $11 \beta$-hydroxysteroid dehydrogenase (11 $\beta \mathrm{HSD})$ isoforms and corticosteroid receptors across ovarian cycles in rats and humans. The upper panel depicts changes in oestradiol (purple line) and progesterone (brown line) to illustrate the phase of the ovarian cycle. (The broken purple line indicates that oestradiol is not secreted in the luteal phase for nonprimate species). The horizontal coloured bars indicate the stages of the ovarian cycles in rats and humans at which follicular granulosa cells or luteinized granulosa or luteal cells express a particular isoform of $11 \beta \mathrm{HSD}$ or a particular corticosteroid receptor. Note the transient expression of $11 \beta \mathrm{HSD} 2$ in luteal cells coincident with functional regression of the corpus luteum.

during luteinization, concluding that $11 \beta \mathrm{HSD} 1$ upregulation at ovulation is induced by gonadotrophins. As ovulation is an inflammatory event characterized by increased synthesis of interleukins and prostaglandins (Espey, 1980; Terranova and Rice, 1997; Ando et al., 1998), increased generation of anti-inflammatory glucocorticoids by the reductase activity of $11 \beta$ HSD 1 at ovulation may present a physiological mechanism to limit the ovarian inflammatory process (Hillier and Tetsuka, 1998; Andersen, 2002). Certainly, glucocorticoids inhibit the synthesis of both prostaglandins and pro-inflammatory cytokines in the ovary (GoppeltStruebe, 1997; Telleria et al., 1998). As expression of $11 \beta \mathrm{HSD} 1$ is upregulated in granulosa cells by $\mathrm{LH}$ and by pro-inflammatory cytokines such as interleukin $1 \beta$ (IL-1 $\beta$ ) (Evagelatou et al., 1997; Tetsuka et al., 1999b), the synthesis of glucocorticoids via $11 \beta \mathrm{HSD} 1$ may be increased by gonadotrophins or cytokines as an integral aspect of the inflammatory cascade of ovulation. Consistent with this hypothesis, the total and free concentrations of cortisol in human follicular fluid increase in response to the preovulatory LH surge (Fateh et al., 1989; Andersen and Hornnes, 1994; Harlow et al., 1997; Yong et al., 2000). The increase in free cortisol also involves competitive displacement of cortisol from cortisol-binding globulin by the high concentrations of progesterone within the ovulatory follicle (Andersen and Hornnes, 1994; Harlow et al., 1997; Andersen, 2002).

Whilst accepting the roles for $\mathrm{LH}$ and interleukins in the transition from expression of $11 \beta \mathrm{HSD} 2$ to expression of $11 \beta \mathrm{HSD} 1$ at ovulation, this periovulatory switch in enzyme isoforms at luteinization could also involve steroidal regulation of enzyme expression. Specifically, $11 \beta$ HSD2 expression in follicular granulosa cells may be dependent on local synthesis of oestrogens, whereas progesterone may suppress expression of $11 \beta \mathrm{HSD} 2$ or induce expression of $11 \beta \mathrm{HSD} 1$ in luteinizing cells. Evidence to support a role for progesterone was obtained in a study of the pregnant rat corpus luteum. In this transient endocrine gland, expression of $11 \beta \mathrm{HSD} 1$ is high until the last day of pregnancy when the corpus luteum undergoes functional regression. At this time, $11 \beta \mathrm{HSD} 1$ expression decreases markedly with a resurgence in expression of 11ßHSD2 (Waddell et al., 1996) (Fig. 3). The simplest interpretation of this observation is that upregulation of $11 \beta \mathrm{HSD} 1$ and suppression of $11 \beta \mathrm{HSD} 2$ at luteinization is dependent on progesterone, such that the decline in progesterone output with luteal regression causes a parallel loss of $11 \beta \mathrm{HSD} 1$ expression accompanied by an increase in $11 \beta \mathrm{HSD} 2$ expression. In a recent study of human granulosa lutein cells undergoing functional luteinization in vitro, this possibility has been examined. Whereas suppression of progesterone synthesis increased both the oxidative and reductive activities of $11 \beta \mathrm{HSD}$ (reflecting decreased competitive inhibition by progesterone), expression of $11 \beta \mathrm{HSD} 1$ protein was unaffected by progesterone suppression and increased progressively as cells luteinized (Thurston et al., 2003c). Hence, upregulation of $11 \beta \mathrm{HSD} 1$ expression in luteinizing cells does not rely on local synthesis of progesterone.

Tetsuka et al. (2003) reported data for the bovine ovary which differ fundamentally from the observations of ovarian cells in humans and rats. Bovine granulosa cells in large antral follicles expressed only mRNA encoding $11 \beta \mathrm{HSD} 1$ whereas $11 \beta \mathrm{HSD} 2 \mathrm{mRNA}$ was not detected by RT-PCR. In the corpus luteum in cows, both $11 \beta \mathrm{HSD} 1$ and $11 \beta \mathrm{HSD} 2$ were co-expressed, with $11 \beta \mathrm{HSD} 1 \mathrm{mRNA}$ predominating in the active corpus luteum and $11 \beta \mathrm{HSD} 2$ predominating in the regressing corpus albicans (Tetsuka et al., 2003). Hence, although enzyme expression does change with the functional activity of follicles and corpus luteum, the cow does not show the absolute switch from expression of $11 \beta \mathrm{HSD} 2$ to $11 \beta \mathrm{HSD} 1$ at ovulation. The species specificity of this phenomenon further proves that the transition between $11 \beta \mathrm{HSD}$ isoforms as granulosa cells in rats and humans luteinize cannot be ascribed solely to changes in follicular and luteal steroid production. In large antral follicles in cows, the synthesis of oestradiol is not accompanied by expression of $11 \beta \mathrm{HSD} 2$, and in the corpus luteum in cows, $11 \beta \mathrm{HSD} 2$ is expressed in the absence of oestradiol and in the presence of progesterone.

With respect to luteinizing granulosa cells in humans, the issue of whether $11 \beta \mathrm{HSD} 1$ acts in these cells as either a reductase or an oxidase has been disputed by 
independent studies (Michael et al., 1997; Thomas et al., 1998). It seems likely that in granulosa lutein cells, as in rat Leydig cells, the predominant direction of action is influenced by subtle factors such as cell differentiation or age and differences between culture media. In studying the detailed kinetics of $11 \beta \mathrm{HSD}$ in granulosa lutein cell homogenates in humans, an $\mathrm{NADP}^{+}$-dependent enzyme activity that appeared to act predominantly as an $11 \beta$ dehydrogenase with a high affinity for cortisol $\left(K_{\mathrm{m}}=\right.$ $400 \mathrm{nmol} \mathrm{I}^{-1}$ ) was identified (Michael et al., 1997). The biochemical properties of this ovarian enzyme activity are very similar to the high affinity $11 \beta \mathrm{HSD}$ activity described in Leydig cells in rats (Ge et al., 1997b).

\section{$11 \beta \mathrm{HSD}$ in the ovarian surface epithelium}

Historically, studies of ovarian function have overlooked the surface epithelium in favour of more dynamic ovarian events and structures. However, emerging evidence indicates that this single-layered epithelium participates in repair of the ovarian surface after the 'wounding' of ovulation. Recent studies have shown that human ovarian surface epithelial (OSE) cells express 11ßHSD1, which is upregulated by pro-inflammatory cytokines, such as IL-1 $\alpha$ (Yong et al., 2002). Regeneration of cortisol by the reductive activity of $11 \beta \mathrm{HSD} 1$ may create an anti-inflammatory environment as part of a co-ordinated response to the preovulatory LH surge (Yong et al., 2002). In addition, ovulation also involves collagenolysis and tissue remodelling at the ovarian surface with apoptosis of OSE cells from the follicular apex (Murdoch et al., 1999). Therefore, the remaining 'bystander' OSE cells surrounding the ovulatory follicle and, after ovulation, the ovulatory rupture site, may play functional roles both in the tissue breakdown that precedes ovulation and in repair of the damaged ovarian surface. These 'bystander' OSE cells are spared from apoptotic damage (Murdoch et al., 1999), indicating that a highly localized inflammatory environment is present at ovulation. In the OSE cells, $11 \beta \mathrm{HSD} 1$ will participate in the local generation of cortisol at and around the site of ovulation to facilitate increased anti-inflammatory and surface repair mechanisms (Yong et al., 2002). In human OSE cells in vitro, cortisol inhibits the induction of metalloproteinase activity by pro-inflammatory cytokines (Rae et al., 2003).

\section{Ovarian 11ßHSD and assisted conception}

Michael et al. (1995) reported an inverse correlation between levels of oxidation of cortisol by $11 \beta \mathrm{HSD}$ in granulosa lutein cells in humans and the clinical outcome of gonadotrophin-stimulated assisted conception cycles. Whereas none of the in vitro fertilization-embryo transfer (IVF-ET) cycles characterized by detectable net conversion of cortisol to cortisone resulted in conception, the probability of establishing a clinical pregnancy in IVF-ET cycles characterized by undetectably low ovarian $11 \beta \mathrm{HSD}$ activities was $64 \%$ (Michael et al., 1995). As ovarian $11 \beta \mathrm{HSD}$ activities were only weakly associated with the probability of oocyte fertilization in vitro (Michael et al., 1995), it was concluded that ovarian $11 \beta \mathrm{HSD}$ activities in the granulosa lutein cells reflected the development potential of ova after fertilization. In patients studied over consecutive treatment cycles, ovarian $11 \beta \mathrm{HSD}$ activities appeared to be a feature of the ovarian response to treatment in a particular IVF-ET cycle for a given patient (Michael et al., 1995).

In an independent study, Thomas et al. (1998) found no significant difference between mean ovarian $11 \beta \mathrm{HSD}$ activities in conception versus non-conception IVF cycles, although the probability of conception was threefold higher in patients with low ovarian $11 \beta \mathrm{HSD}$ activities than in patients whose granulosa lutein cells exhibited high rates of cortisol-cortisone interconversion. Subsequently, the ratio of cortisol:cortisone in follicular fluid was assessed as a reflection of $11 \beta \mathrm{HSD}$ activities within follicles in vivo. In gonadotrophin-stimulated IVF-ET cycles, high follicular cortisol:cortisone ratios have been found to be associated with a greater than $50 \%$ probability of conception, whereas low follicular cortisol:cortisone ratios are typically associated with a probability of establishing a pregnancy through IVF-ET of less than 10\% (Michael et al., 1999; Thurston et al., 2003d). Although a study by Andersen et al. (1999) found no significant correlation between IVF outcome and follicular cortisol:cortisone ratios, Keay et al. (2002) reported a significant association between increased follicular cortisol:cortisone ratios and the probability of conception in women undergoing natural cycle IVF. High cortisol:cortisone ratios in follicular fluid aspirated from women who conceive by IVF-ET would reflect either a low net oxidation of cortisol to cortisone in the mature follicle (in agreement with the present authors' initial observations) or an increase in the opposing reduction of cortisone to cortisol.

\section{Ovarian modulators of $11 \beta \mathrm{HSD}$ : IVF outcome, ovarian cysts and apparent cortisone reductase deficiency}

In initial studies, granulosa lutein cells were stored for up to 3 days in follicular fluid before being isolated and cultured. Thurston et al. (2002, 2003e) have showed that follicular fluid from women, cows and pigs contains at least two distinct classes of compound capable of selectively modulating the $\mathrm{NADP}(\mathrm{H})$-dependent activities of the $11 \beta \mathrm{HSD} 1$ isoform. Specifically, follicular fluid contains a hydrophilic compound(s) that can stimulate $11 \beta \mathrm{HSD} 1$ activity by up to threefold within $1 \mathrm{~h}$, and a hydrophobic component(s) that acutely inhibits $11 \beta \mathrm{HSD} 1$ activity by up to $84 \%$. 


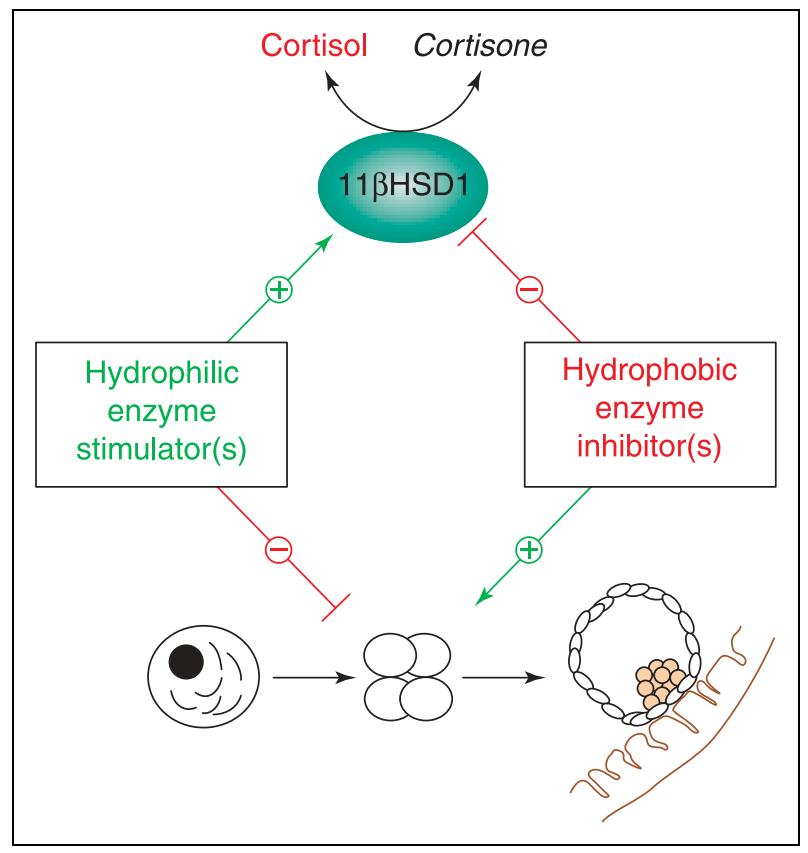

Fig. 4. Independent effects of ovarian modulators of $11 \beta$ hydroxysteroid dehydrogenase $(11 \beta \mathrm{HSD})$ on $11 \beta \mathrm{HSD} 1$ activity and the developmental potential of the oocyte. Green lines with a positive symbol indicate a stimulatory effect on enzyme activity or on the developmental potential of the oocyte or embryo. Red lines with a negative symbol indicate an inhibitory effect on enzyme activity or on the developmental potential of the oocyte or embryo.

Within human follicular fluid, high activity of the hydrophilic stimulator(s) of $11 \beta \mathrm{HSD} 1$ correlates with a low intrafollicular cortisol:cortisone ratio and predicts a low probability of conception, whereas high activity of the hydrophobic inhibitor(s) of $11 \beta \mathrm{HSD} 1$ are associated with a high cortisol:cortisone ratio and an increased likelihood of establishing a clinical pregnancy (Thurston et al., 2003d). Hence, in the present authors' initial studies, low $11 \beta \mathrm{HSD}$ activities may have reflected the activity of enzyme modulators present in the follicular fluid samples in which cells were stored before culture. The working model is that the association between the follicular content of enzyme stimulator(s), enzyme inhibitor(s) and IVF outcome reflects independent effects of these as yet unidentified compounds on ovarian glucocorticoid metabolism and the developmental competence of oocytes in maturing follicles (Fig. 4).

In ovaries in cows and pigs, aspirates from spontaneous ovarian cysts contain much lower contents of the hydrophilic stimulator(s) of NADP(H)-dependent glucocorticoid metabolism and higher contents of the hydrophobic inhibitor(s) of $11 \beta$ HSD1 than does follicular fluid aspirated from large antral follicles (Thurston et al., 2003e). If this picture within follicular and ovarian cyst fluid is reflective of circulating modulators of $11 \beta \mathrm{HSD} 1$ activities, this could explain, at least in part, the association between polycystic ovaries and ACRD in

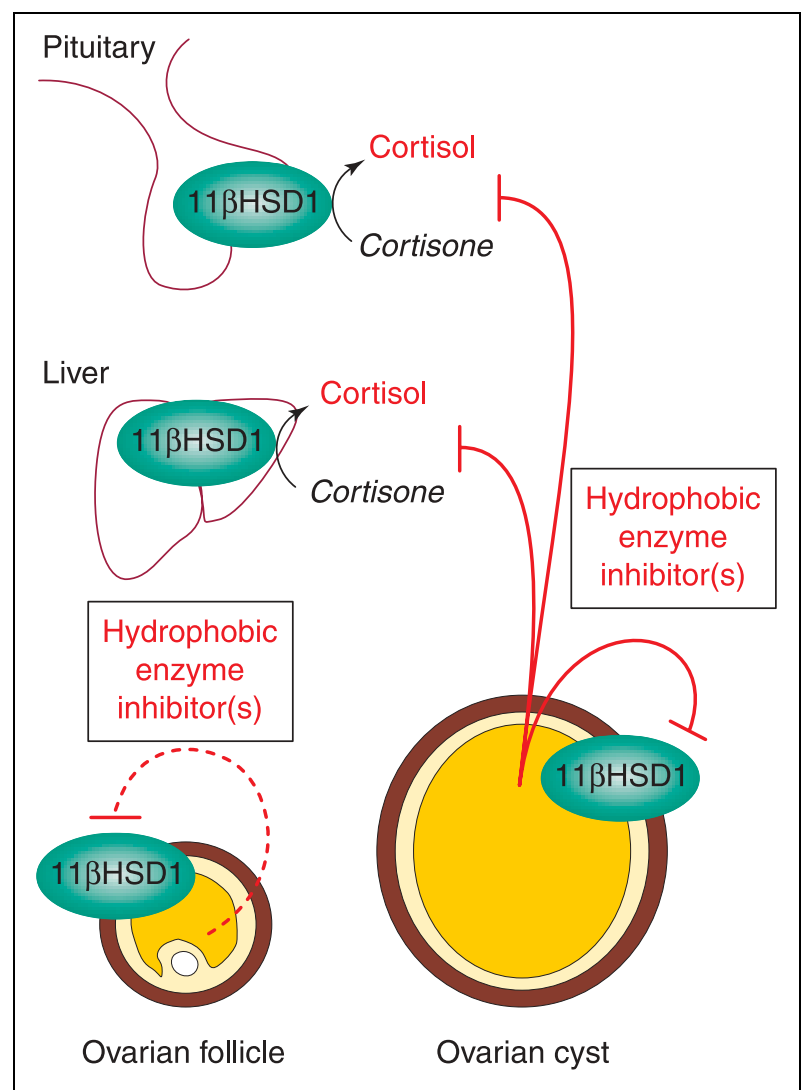

Fig. 5. Contrasting paracrine and endocrine actions of hydrophobic ovarian inhibitors of $11 \beta$-hydroxysteroid dehydrogenase 1 (11ßHSD1) produced by a maturing ovarian follicle versus an ovarian cyst. Red lines indicate a paracrine or endocrine inhibition of cortisol-cortisone inter-conversion by $11 \beta \mathrm{HSD} 1$ in the ovary, liver or pituitary gland. Broken lines indicate relatively weak inhibition; solid lines indicate relatively strong inhibition.

hyperandrogenic, anovulatory women (Fig. 5). Certainly, in patients with ACRD, no mutations have yet been identified in the HSD11B1 gene (Nikkila et al., 1993; Jamieson et al., 1999), indicating a post-transcriptional defect in the reductase activity of hepatic $11 \beta \mathrm{HSD} 1$. The present authors, based on latest findings, would attribute ACRD to a post-translational inhibition of hepatic $11 \beta$ HSD1 activity in cystic ovarian disease, possibly due to increased secretion of a hydrophobic inhibitor of $11 \beta \mathrm{HSD} 1$ from the ovarian cysts. Given that $11 \beta \mathrm{HSD} 1$ is required in the pituitary gland for glucocorticoids to suppress ACTH synthesis and secretion (Harris et al., 2001), the present authors propose that in cystic ovarian disease, increased circulating concentrations of the hydrophobic inhibitor(s) of $11 \beta \mathrm{HSD} 1$ not only alters hepatic glucocorticoid metabolism, but also impedes negative feedback within the HPA axis. The consequent increase in pituitary ACTH secretion would then, in turn, contribute to the stimulation of adrenal hyperandrogenism typical of cystic ovarian disease (Fig. 5). Although it is yet to be proved definitively that the 
inhibitor(s) of $11 \beta \mathrm{HSD} 1$ present in follicular or cyst fluid arise locally within the ovaries, the fact that first degree male relatives of women with ACRD show normal hepatic cortisone reductase activity (Jamieson et al., 1999) supports the view that the major inhibitor of $11 \beta$ HSD 1 is produced in a tissue or gland found only in females.

\section{$11 \beta H S D$ in the uterus}

In the uterus, both cloned isoforms of $11 \beta \mathrm{HSD}$ cooperate to control access of glucocorticoids to the glucocorticoid receptors (rather than the mineralocorticoid receptors). Initial studies of rat uteri found that $11 \beta \mathrm{HSD} 1 \mathrm{mRNA}$ expression varied across the oestrous cycle from a peak at dioestrus to a nadir at oestrus, consistent with suppression of $11 \beta \mathrm{HSD} 1$ by oestrogens (Albiston et al., 1995). Subsequent studies confirmed that uterine expression of both $11 \beta \mathrm{HSD} 1$ and $11 \beta \mathrm{HSD} 2$ is indeed oestrogen sensitive (Burton et al., 1998). However, studies of $11 \beta$ HSD1 expression in liver and hippocampus established that in these tissues, suppression of $11 \beta \mathrm{HSD} 1 \mathrm{mRNA}$ by oestradiol is mediated indirectly via increased plasma growth hormone (Low et al., 1994). The suppression of $11 \beta \mathrm{HSD} 1$ expression by growth hormone is in turn mediated by insulin-like growth factor 1 (IGF-I) (Moore et al., 1999). As the IGF system is active in the uterus, expression of $11 \beta \mathrm{HSD} 1$ here is likely to be controlled by both direct effects of oestradiol and indirect effects mediated via IGF-I. As in the ovary, expression of $11 \beta \mathrm{HSD} 1 \mathrm{mRNA}$ in the uterus in rats can also be increased by gonadotrophins (Ho et al., 1999), although indirect effects secondary to stimulation of ovarian steroidogenesis cannot be excluded.

Within the myometrium, glucocorticoids exert important effects on such parameters as myometrial contractility (Challis et al., 2000) and expression of oestrogen receptors (Wu et al., 1996). In the uteri in rats, 11ßHSD1 and $11 \beta \mathrm{HSD} 2$ have both been co-localized with glucocorticoid receptors in the myometrial smooth muscle cells (Burton et al., 1996a; Waddell and Burton, 2000; Burton and Waddell, 2002). Myometrial expression of $11 \beta \mathrm{HSD} 2 \mathrm{mRNA}$ and protein both increase from day 10 of pregnancy, peak at day 16 of gestation, and are significantly suppressed within $24 \mathrm{~h}$ after birth (Burton and Waddell, 2002). However, in pregnancy, $\mathrm{NAD}^{+}$-dependent oxidation of corticosterone is suppressed (rather than increased) relative to the non-pregnant rat myometrium, and remains constantly low throughout pregnancy, returning to pre-conception values within $24 \mathrm{~h}$ of parturition. This apparent paradox reflects competitive inhibition of myometrial $11 \beta \mathrm{HSD} 2$ by progesterone throughout pregnancy (Burton and Waddell, 2002). During pregnancy, the expression of $11 \beta \mathrm{HSD} 1 \mathrm{mRNA}$ and protein in the rat myometrium also increases markedly to a maximum on day 22 of gestation (that is 1 day before birth), decreasing to non-pregnant values by day 1 after birth (Burton et al., 1996a; Waddell and Burton, 2000; Burton and Waddell, 2002). Unlike 11ßHSD2, the 30 -fold increase in expression of $11 \beta \mathrm{HSD} 1$ at term is accompanied by a 10 -fold increase in the 11-ketosteroid reductase activity which peaks on the day before parturition (Burton et al., 1996a; Waddell and Burton, 2000). As the oxidative activity of myometrial 11ßHSD2 remains constant throughout pregnancy, the pre-partum induction of $11 \beta \mathrm{HSD} 1$ favours net regeneration of active glucocorticoids within the myometrium (Burton and Waddell, 2002). As discussed below, this change from inactivation to regeneration of glucocorticoids within the myometrium assists in parturition. However, this role for myometrial $11 \beta \mathrm{HSD}$ is species specific as there is little detectable expression of $11 \beta \mathrm{HSD} 1 \mathrm{mRNA}$ in the myometrium in sheep from day 60 of gestation to 2 days before term (Yang et al., 1996).

Although the data reviewed above indicate upregulation of myometrial $11 \beta \mathrm{HSD} 1$ by progesterone as pregnancy progresses, Waddell and Burton (2000) observed that in unilaterally pregnant rats there was only limited endocrine upregulation of $11 \beta \mathrm{HSD} 1 \mathrm{mRNA}$ in the contralateral, non-gravid uterine horn, concluding that full induction of myometrial $11 \beta \mathrm{HSD} 1$ expression in the gravid horn was reliant on paracrine factors. This comprehensive study established that paracrine upregulation of $11 \beta \mathrm{HSD} 1$ expression and activity in the pregnant uterine horn was attributable to the placenta rather than to uterine distension or to the presence of a fetus. Waddell and Burton (2000) concluded that placental hormones (for example placental cytokines) are required for local upregulation of myometrial $11 \beta \mathrm{HSD} 1$ in pregnancy.

In the uterine endometrium, in myomorph rodents and sheep, $11 \beta \mathrm{HSD} 1$ is absent from the endometrial stroma and glandular epithelium, but has been localized to the luminal epithelium where it is co-expressed with glucocorticoid receptors (Yang et al., 1996; Burton et al., 1998; Thompson et al., 2002). As in the myometrium, endometrial expression of $11 \beta \mathrm{HSD} 1$ mRNA is increased in the luteal phase of the oestrous cycle and in pregnancy, reflecting upregulation by progesterone (Yang et al., 1996). In cultured human endometrial stroma cells, the expression and activity of $11 \beta \mathrm{HSD} 1$ was increased by treatment of cells with progesterone for 3 days. Although treatment with oestradiol alone had no effect, co-treatment of stromal cells with oestradiol potentiated the induction of $11 \beta \mathrm{HSD} 1$ by progesterone. This observation led Arcuri et al. (1996) to conclude that upregulation of $11 \beta \mathrm{HSD} 1$ is a feature of endometrial decidualization.

In the endometrium of pregnant rats and mice, $11 \beta \mathrm{HSD} 2$ is expressed only in the sub-epithelial stroma, and there is no detectable expression in the uterine epithelia (Burton and Waddell, 2002; Thompson et al., 
2002). In contrast, in the endometrium of non-pregnant women, there is limited expression of $11 \beta \mathrm{HSD} 2$ in the stroma, but this oxidative enzyme isoform is highly expressed in both the glandular and luminal epithelia (Smith et al., 1997). Although endometrial 11ßHSD2 activity increases in the secretory phase of the menstrual cycle, this almost certainly reflects expansion of the glandular epithelium under the action of progesterone (Smith et al., 1997). Although roles for endometrial $11 \beta \mathrm{HSD}$ have been proposed in pregnancy (particularly for the decidua), the physiological roles for glucocorticoid metabolism in the non-pregnant endometrium have yet to be defined.

\section{$11 \beta H S D$ in pregnancy}

Early studies of glucocorticoid metabolism focused on human placenta as a source of enzyme activity (Osinski, 1960; Murphy et al., 1974). As the complex role for $11 \beta \mathrm{HSD}$ in this organ has been discussed in several excellent reviews (for example Yang, 1997; Burton and Waddell, 1999; Bertram and Hanson, 2002), coverage in the current review will focus on major points of note and recent developments.

In the placenta of all species studied to date, there are two biochemically distinct $11 \beta \mathrm{HSD}$ activities which have been attributed to the co-expression of both $11 \beta \mathrm{HSD} 1$ and 11ßHSD2 (Murphy, 1981; Lakshmi et al., 1993; Yang, 1995; Burton et al., 1996b; Pepe et al., 1996; Sun et al., 1997a; Thompson et al., 2002). 11ßHSD1 is predominantly expressed in the decidua, chorion, amnion and vascular endothelial cells, whereas $11 \beta \mathrm{HSD} 2$ is expressed in both the decidua and in the placenta (Murphy, 1981; Sun et al., 1997a; Burton and Waddell, 1999; Driver et al., 2001; Thompson et al., 2002). In the baboon placenta, $11 \beta \mathrm{HSD} 1$ and $11 \beta \mathrm{HSD} 2$ are coexpressed in the syncitiotrophoblast (Pepe et al., 1996), and in the mouse placenta, both cloned isoforms of $11 \beta \mathrm{HSD}$ are co-expressed with glucocorticoid receptors in the labyrinthine zone in the later stages of gestation (Thompson et al., 2002). In all species, this localization of $11 \beta \mathrm{HSD} 2$ at the materno-fetal interface reflects the role for $11 \beta \mathrm{HSD} 2$ as a mechanism to limit transfer of glucocorticoids between the maternal and fetal circulations.

At different stages of gestation, the balance between the reductase activity of $11 \beta \mathrm{HSD} 1$ and the oxidative activity of $11 \beta \mathrm{HSD} 2$ in the placenta changes in a speciesspecific manner. In ewes and guinea-pigs, placental $11 \beta$-dehydrogenase activity decreases as pregnancy progresses (Yang, 1997; Sampath-Kumar et al., 1998), whereas in human, baboon, pig and rat placentas, $11 \beta$ dehydrogenase activity increases in the later stages of gestation (Lopez-Bernal et al., 1980; Pepe et al., 1988; Klemcke and Christenson, 1996; Burton and Waddell, 1999). Although the net oxidative activity of $11 \beta \mathrm{HSD}$ increases at term in the rat placenta, this reflects increa- sing expression of $11 \beta \mathrm{HSD} 2$ in the basal zone of the placenta (the major site of placental hormone synthesis), which masks a decrease in the expression and activity of $11 \beta \mathrm{HSD} 2$ in the labyrinthine zone (the site of fetomaternal exchange) (Burton et al., 1996b).

As in other reproductive tissues, the expression and activities of placental $11 \beta \mathrm{HSD}$ isoforms is hormonally regulated. For example, in the placenta in sheep, suppression of $11 \beta \mathrm{HSD} 2$ activity at term is mediated by cortisol (Clarke et al., 2002). In placental and chorionic trophoblasts in humans, both progesterone and oestradiol selectively inhibit the oxidative activity of $11 \beta \mathrm{HSD} 2$ without affecting $11 \beta \mathrm{HSD} 1$ reductase activity (Sun et al., 1998). In addition, progesterone represses the expression of $11 \beta$ HSD2 mRNA (Sun et al., 1998). Expression or activity of this high affinity $11 \beta$-dehydrogenase is also inhibited in human term placental trophoblasts by noradrenaline (Sarkar et al., 2001), nitric oxide (mediated, at least in part, via cyclic GMP) (Sun et al., 1997b), prostaglandins and leukotriene $B_{4}$ (which inhibit enzyme activity at the post-transcriptional level via increased intracellular calcium) (Hardy et al., 1999, 2001). In contrast to these suppressive actions, placental $11 \beta \mathrm{HSD} 2$ is selectively upregulated by cyclic AMP (Sun et al., 1998). As $11 \beta \mathrm{HSD} 2$ does not contain a consensus phosphorylation sequence for the cyclic AMP-dependent kinase, PKA, the selective upregulation of placental $11 \beta \mathrm{HSD} 2$ must be attributable either to a direct effect of cyclic AMP on the enzyme (via interaction with the ATP-binding site) or to an effect on enzyme translation or stability. (The endocrine regulation of $11 \beta \mathrm{HSD} 1$ expression and activity in the placenta is of primary importance at parturition, and so will be discussed below.)

Recent studies have focused on the regulation of placental $11 \beta \mathrm{HSD} 2$ by hypoxia. Although two studies have shown that hypoxia represses expression of $11 \beta \mathrm{HSD} 2$ (without affecting 11ßHSD1) in term human trophoblasts and villous explants (Alfaidy et al., 2002; Hardy and Yang, 2002), Driver et al. (2002) found that hypoxia upregulates $11 \beta \mathrm{HSD} 2$ and have identified a hypoxiainducible factor 1 response element in the 11ßHSD2 promoter. Moreover, decreased oxygen tension indirectly influences the activities of placental $11 \beta \mathrm{HSD}$ by altering the redox balances of pyridine nucleotide cofactors in favour of NADPH (so favouring the reductive activity of $11 \beta \mathrm{HSD} 1$ ) and $\mathrm{NADH}$ (thereby limiting the $\mathrm{NAD}^{+}-$ dependent oxidative activity of $11 \beta \mathrm{HSD} 2$ ). In either event, the placental hypoxia associated with preeclampsia alters the trans-placental passage of glucocorticoids from mother to fetus and the local balance of glucocorticoid regeneration from 11-ketosteroids (Alfaidy et al., 2002).

Endogenous inhibitors of glucocorticoid metabolism have been described in human urine (Morris et al., 1992). Pending identification, these compounds were named 'glycyrrhetinic acid-like factors' (GALFs), reflecting their ability to inhibit both $11 \beta \mathrm{HSD}$ and $5 \beta$-reductase: 
characteristic actions of the liquorice derivative, glycyrrhetinic acid. The urinary GALF content, which is higher in women than men, increases progressively during pregnancy (Morris et al., 1992), consistent with production of GALF by the ovary or placenta. Although GALF and identified inhibitor(s) of $11 \beta \mathrm{HSD} 1$ from follicular fluid share similar biophysical properties (Thurston et al., 2002), it can only be speculated at present that the urinary GALFs and ovarian enzyme inhibitor(s) may be related (if not the same) compounds.

\section{$11 \beta \mathrm{HSD}$, fetal development and intra-uterine growth retardation}

The widely accepted view is that in the placenta, $11 \beta$ HSD2 serves as a barrier to limit transfer of active glucocorticoids from mother to fetus. Hence, if placental $11 \beta \mathrm{HSD} 2$ activity is compromised, increased transport of glucocorticoids (before activation of the fetal HPA axis) stimulates premature differentiation of fetal tissues, limiting subsequent tissue growth and culminating in growth retardation. This model was first advanced by Benediktsson et al. (1993) after observing a direct correlation between placental 11ßHSD activities and fetal weights in rats at term. That placental $11 \beta \mathrm{HSD}$ activities are decreased in pregnancies complicated by IUGR was subsequently corroborated in studies of pregnancies in humans (Shams et al., 1998; McTernan et al., 2001). However, it is important to note that within the fetus, both cloned isoforms of $11 \beta \mathrm{HSD}$ are widely expressed in a tissue-specific manner (Murphy, 1981; Stewart et al., 1994). Hence, any decrease in placental inactivation of glucocorticoids may not necessarily influence the concentrations to which individual fetal tissues are exposed. It seems far more likely that the exposure of fetal tissues to glucocorticoids is determined at the intracrine level by the activities of $11 \beta \mathrm{HSD} 1$ and $11 \beta \mathrm{HSD} 2$, rather than at the relatively distant level of the placenta.

Recent studies have demonstrated that maternal nutrient restriction at defined stages of pregnancy results in both fetal growth retardation and in significant decreases in the expression and activity of placental $11 \beta$ HSD2 (Bertram et al., 2001; Lesage et al., 2001). Although this would permit increased passage of active glucocorticoid into the fetal circulation, it is not possible to comment on the physiological significance of the decrease in placental glucocorticoid metabolism versus changes in the expression or activities of $11 \beta \mathrm{HSD}$ within affected fetuses.

Although the relative impact of placental versus fetal $11 \beta \mathrm{HSD}$ in modulating fetal exposure to glucocorticoids remains contentious, $11 \beta \mathrm{HSD}$ enzymes in tissues such as the decidua are able to influence fetal development in utero. Specifically, $11 \beta \mathrm{HSD} 1$ acts in the decidua to increase the concentration of active glucocorticoid in amniotic fluid. As the amniotic fluid bathes the fetal lungs, a high cortisol:cortisone (or corticosterone:11dehydrocorticosterone) ratio in amniotic fluid promotes maturation of the fetal lungs. To guard against premature lung maturation, the fetal lung expresses the oxidative $11 \beta \mathrm{HSD} 2$ enzyme throughout the first and second trimester (Murphy, 1981; Stewart et al., 1994), but in late gestation, this oxidative enzyme is replaced by the reductive $11 \beta \mathrm{HSD} 1$ enzyme, so allowing glucocorticoid derived from the amniotic fluid to stimulate synthesis of lung surfactant.

\section{$11 \beta H S D$ and parturition}

Over the past 5 years, studies conducted primarily by Challis and colleagues have implicated the reductive activity of $11 \beta \mathrm{HSD} 1$ in the mechanism of parturition (Fig. 6). Specifically, it has been proposed that glucocorticoids generated by $11 \beta \mathrm{HSD} 1$ in the myometrium and decidua increase (rather than suppress) uterine concentrations of prostaglandins which stimulate contractions of the myometrium to expel the fetus (reviewed by Challis et al., 2000). This unusual pro-inflammatory (rather than anti-inflammatory) action of glucocorticoids at term involves upregulation of prostaglandin $\mathrm{H}$ synthase 2 accompanied by suppression of PGDH in the chorion (Patel et al., 1999; Whittle et al., 2001) (Fig. 6). PGDH, which normally oxidizes prostaglandins to inactive metabolites, belongs to the same enzyme superfamily as the $11 \beta \mathrm{HSD}$ enzymes, and shares over $90 \%$ primary sequence homology at the active site with $11 \beta \mathrm{HSD} 1$ (Penning, 1997).

Within the placenta, prostaglandins increase both the expression and activity of $11 \beta \mathrm{HSD} 1$ (Alfaidy et al., 2001). The consequent increase in the concentration of active glucocorticoids is further enhanced by the abilities of prostaglandins $E_{2}$ and $F_{2 \alpha}$ to inhibit the oxidative $11 \beta$ HSD2 isoform in the placenta (Hardy et al., 1999). Recent studies have shown that glucocorticoids can also upregulate placental $11 \beta \mathrm{HSD} 1$ expression (Sun et al., 2002) and suppress the inactivation of glucocorticoids by placental $11 \beta \mathrm{HSD} 2$ (Clarke et al., 2002), thereby accelerating the paracrine glucocorticoid-prostaglandin spiral (Fig. 6).

At term, this positive feed-forward loop may be activated by glucocorticoids generated as the fetal HPA axis matures (Whittle et al., 2001). However, this mechanism could also participate in the initiation of pre-term labour following an increase in either maternal or fetal glucocorticoids (and catecholamines) under conditions of maternal or fetal stress. In addition, this paracrine positive feed-forward loop provides a mechanism whereby increase of uterine prostaglandin concentrations (for example in response to an intrauterine infection) would prematurely trigger parturition. As placental $11 \beta \mathrm{HSD} 2$ appears to be sensitive to oxygen tension, changes in glucocorticoid metabolism have also been implicated in the mechanism of pre-term labour 


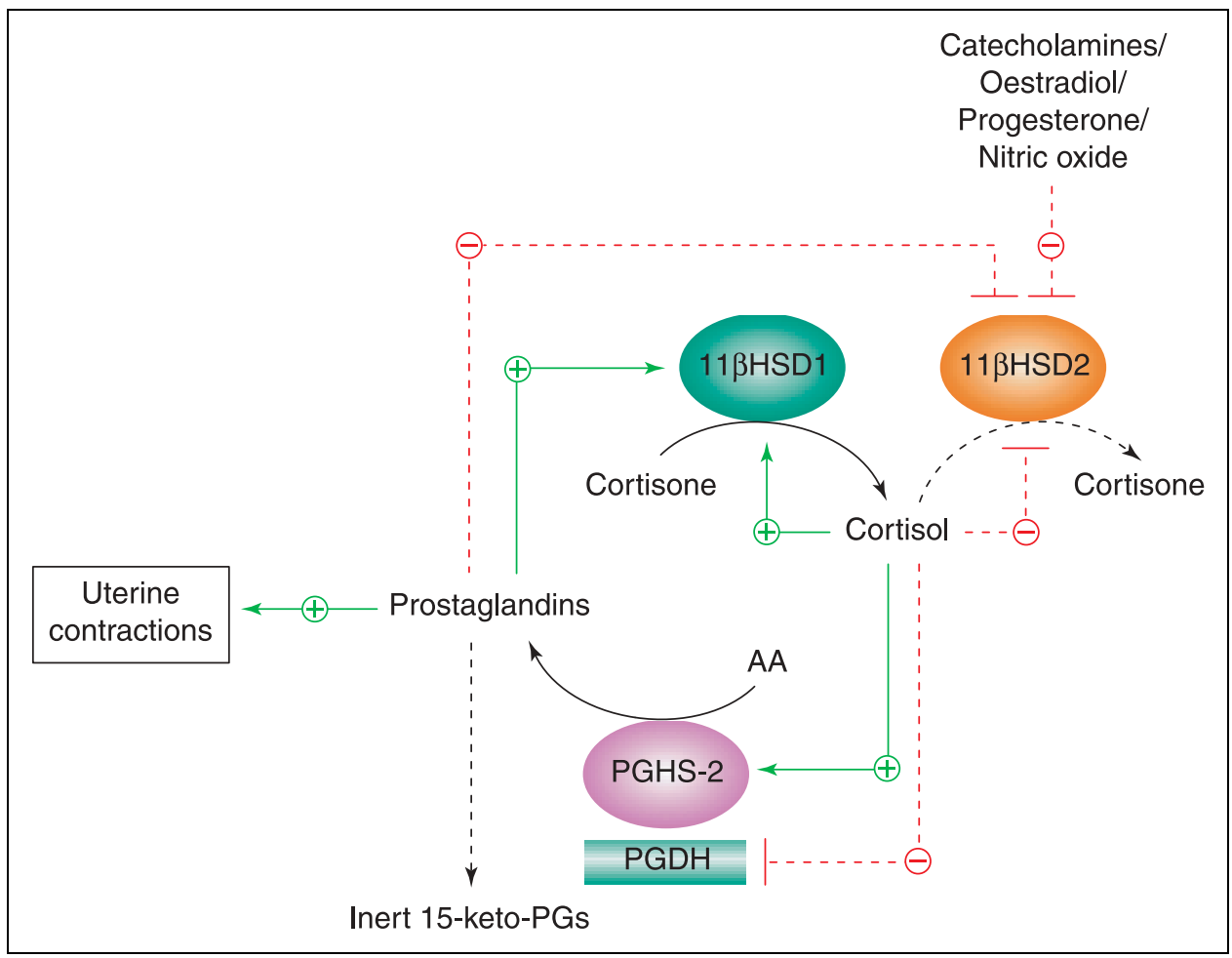

Fig. 6. A potential glucocorticoid-prostaglandin paracrine feed-forward loop contributing to the mechanism of parturition. Black lines indicate an enzyme-catalysed reaction; solid black lines are used for major metabolic pathways; and broken lines indicate minor pathways. Solid green lines with a positive symbol indicate a stimulatory effect on the expression or activity of the appropriate enzyme, or on myometrial contraction. Broken red lines with a negative symbol indicate an inhibitory effect on the expression or activity of the appropriate enzyme. AA: arachidonic acid; $11 \beta \mathrm{HSD} 1$ : 11ß-hydroxysteroid dehydrogenase 1; PGDH: 15-hydroxyprostaglandin dehydrogenase; PGHS-2: prostaglandin $\mathrm{H}$ synthase 2 .

in hypoxic states such as pre-eclampsia (Alfaidy et al., 2002).

\section{$11 \beta H S D$ and the mammary gland}

Within the mammary gland, oxidative $11 \beta \mathrm{HSD}$ activity is 20-fold higher in adipose cells than in mammary epithelial cells (Quirk et al., 1990). Moreover, whereas $11 \beta \mathrm{HSD}$ activities are comparably high in mammary cells from virgin and pregnant rats, the ability of $11 \beta \mathrm{HSD}$ to inactivate glucocorticoids decreases by over $75 \%$ during lactation (Quirk et al., 1990). As glucocorticoids induce the expression of milk proteins such as casein and lactalbumin (Ono and Oka, 1980), the postpartum decrease in glucocorticoid oxidation is a prerequisite for the endocrine induction of lactogenesis (Quirk et al., 1990), whereas inactivation of glucocorticoids within the mammary gland prevents futile antagonism between the positive effects of glucocorticoids and the suppressive actions of progesterone during pregnancy. As to the mechanism for the decrease in mammary $11 \beta \mathrm{HSD}$ activities during lactation, this is unlikely to reflect changes in gonadal or placental steroids as enzyme activities were the same in virgin versus pregnant rats. Instead, the decrease in mammary $11 \beta \mathrm{HSD}$ activities probably reflects unique changes to the endocrine milieu of the mammary gland post partum (for example increased prolactin levels).

Hundertmark et al. (1997) reported inactivation of physiological and synthetic glucocorticoids by $11 \beta \mathrm{HSD}$ in the MCF-7 and ZR-75-1 human breast cancer cell lines. As the cells exhibited only limited 11ketosteroid reductase activity, and because the oxidation of glucocorticoids could be inhibited by glycyrrhetinic acid, these authors concluded that $11 \beta \mathrm{HSD} 2$ is the predominant enzyme isoform in the human breast. Moreover, inhibition of $11 \beta \mathrm{HSD}$ activity with glycyrrhetinic acid potentiated the anti-proliferative action of prednisolone (Hundertmark et al., 1997), confirming that oxidation modulates the actions of glucocorticoids in mammary cells.

\section{Concluding remarks}

The evidence outlined in this review indicates that the metabolism of glucocorticoids by isoforms of $11 \beta \mathrm{HSD}$ is important in a wide range of reproductive tissues and 
Table 2. Overview of the confirmed and speculative physiological roles for $11 \beta$-hydroxysteroid dehydrogenases (11ßHSD) in reproductive tissues

\begin{tabular}{|c|c|c|c|}
\hline Tissue or organ & Cell & $11 \beta \mathrm{HSD}$ isoform & Proposed physiological role \\
\hline \multirow[t]{2}{*}{ Pituitary } & Corticotrophs & 1 & Maximizes negative feedback on ACTH \\
\hline & Gonadotrophs & $1+2$ & Unknown \\
\hline \multirow[t]{2}{*}{ Testis } & Leydig cells & $1(+?)$ & $\begin{array}{l}\text { Protects testosterone biosynthesis from inhibition by } \\
\text { glucocorticoids }\end{array}$ \\
\hline & Spermatozoa & Unknown & Unknown \\
\hline $\begin{array}{l}\text { Epidydimis/vas } \\
\text { deferens }\end{array}$ & Not specified & 1 & $\begin{array}{l}\text { Modulates control of sodium content/viscosity } \\
\text { of seminal plasma }\end{array}$ \\
\hline \multirow[t]{5}{*}{ Ovary } & Theca cells & 2 & Unknown \\
\hline & Granulosa cells & $2(+?)$ & $\begin{array}{l}\text { Protects oestradiol biosynthesis from inhibition by } \\
\text { glucocorticoids }\end{array}$ \\
\hline & Oocyte & 1 & $\begin{array}{l}\text { Modulates effects of glucocorticoids on } \\
\text { oocyte maturation }\end{array}$ \\
\hline & Luteal cells & $1(+?)$ & $\begin{array}{l}\text { Protects progesterone biosynthesis from inhibition } \\
\text { by glucocorticoids }\end{array}$ \\
\hline & Surface epithelial cells & 1 & $\begin{array}{l}\text { Facilitates anti-inflammatory effects of } \\
\text { glucocorticoids at ovulation }\end{array}$ \\
\hline Myometrium & Smooth muscle cells & $1+2$ & $\begin{array}{l}\text { Modulates actions of glucocorticoids on contractility } \\
\text { and oestrogen receptors }\end{array}$ \\
\hline Endometrium & $\begin{array}{l}\text { Epithelial cells + sub- } \\
\text { epithelial stroma }\end{array}$ & $1+2$ & Unknown \\
\hline \multirow[t]{2}{*}{ Placenta } & $\begin{array}{l}\text { Decidua + chorion + amnion + } \\
\quad \text { vascular endothelial cells }\end{array}$ & 1 & $\begin{array}{l}\text { Facilitates effects of glucocorticoids on } \\
\text { prostaglandin synthesis or metabolism to induce } \\
\text { parturition (implicated in pre-term labour) }\end{array}$ \\
\hline & Decidua + syncitiotrophoblast & 2 & $\begin{array}{l}\text { Limits transfer of cortisol from the maternal to the } \\
\text { fetal circulation (defective in IUGR) }\end{array}$ \\
\hline Mammary gland & Adipose cells & 2 & $\begin{array}{l}\text { Modulates actions of glucocorticoids on } \\
\text { lactogenesis }\end{array}$ \\
\hline
\end{tabular}

1: $11 \beta \mathrm{HSD} 1 ; 2: 11 \beta \mathrm{HSD} 2 ;(+?)$ : the possible existence of an as yet uncloned isoform of $11 \beta \mathrm{HSD}$; ACTH: adrenocorticotrophic hormone; IUGR: intra-uterine growth retardation.

a number of key reproductive processes (summarized in Table 2). The apparent significance of glucocorticoid inactivation or reactivation by $11 \beta \mathrm{HSD}$ in reproductive suppression, ovulation, luteinization, cystic ovarian disease, the developmental potential of oocytes, IUGR, parturition and lactation indicates significant roles for glucocorticoids in each of these fundamental processes.

The authors would like to thank S. G. Hillier and K. C. Jonas for their constructive feedback on early drafts of this review. The original research contributions of the authors to the work reviewed herein has been supported by grants from the BBSRC (48/S15850), Freemedic plc, MRC (project grants G9309070 and G9519816; programme grant 0000066), Stanley Thomas Johnson Foundation, Wellbeing and the Wellcome Trust (052970/Z/97).

\section{References}

Key references are indicated by asterisks.

Agarwal AK, Monder C, Eckstein B and White PC (1989) Cloning and expression of rat CDNA encoding corticosteroid $11 \beta$-dehydrogenase Journal of Biological Chemistry 264 18 939-18943

Agarwal AK, Mune T, Monder C and White PC (1994) NAD ${ }^{+}$-dependent isoform of $11 \beta$-hydroxysteroid dehydrogenase. Cloning and character- ization cDNA from sheep kidney Journal of Biological Chemistry 269 25 959-25962

Albiston AL, Obeyesekere VR, Smith RE and Krozowski ZS (1994) Cloning and tissue distribution of the human $11 \beta$-hydroxysteroid dehydrogenase type 2 enzyme Molecular and Cellular Endocrinology 105 R11-R17

Albiston AL, Smith RE and Krozowski ZS (1995) Changes in the levels of $11 \beta$-hydroxysteroid dehydrogenase mRNA over the oestrous cycle in the rat Journal of Steroid Biochemistry and Molecular Biology 52 $45-48$

*Alfaidy N, Xiong ZG, Myatt L, Lye SG, MacDonald JF and Challis JRG (2001) Prostaglandin $F_{2 \alpha}$ potentiates cortisol production by stimulating $11 \beta$-hydroxysteroid dehydrogenase 1: a novel feedback loop that may contribute to human labor Journal of Clinical Endocrinology and Metabolism 86 5585-5592

Alfaidy N, Gupta S, DeMarco C, Caniggia I and Challis JRG (2002) Oxygen regulation of placental $11 \beta$-hydroxysteroid dehydrogenase 2: physiological and pathological implications Journal of Clinical Endocrinology and Metabolism 87 4797-4805

*Andersen CY (2002) Possible new mechanism of cortisol action in female reproductive organs: physiological implications of the free hormone hypothesis Journal of Endocrinology 173 211-217

Andersen CY and Hornnes P (1994) Intrafollicular concentrations of free cortisol close to follicular rupture Human Reproduction 9 1944-1949

Andersen CY, Morineau G, Fukuda M, Westergaard LG, Ingerslev HJ, Fiet J and Byskov AG (1999) Assessment of the follicular cortisol:cortisone ratio Human Reproduction 14 1563-1568

Ando M, Kol S, Kokia E, Ruutiainen-Altman K, Sirois J, Rohan RM, Payne DW and Adashi EY (1998) Rat ovarian prostaglandin endoperoxide 
synthase-1 and -2: periovulatory expression of granulosa cell-based interleukin-1-dependent enzymes Endocrinology 139 2501-2508

Arcuri F, Monder C, Lockwood CJ and Schatz F (1996) Expression of $11 \beta$-hydroxysteroid dehydrogenase during decidualization of human endometrial stromal cells Endocrinology 137 595-600

Arriza JL, Weinberger C, Cerelli G, Glaser TM, Handelin BL, Housman DE and Evans RM (1987) Cloning of human mineralocorticoid receptor complementary DNA: structural and functional kinship with the glucocorticoid receptor Science 237 268-275

Bambino TH and Hsueh AJ (1981) Direct inhibitory effect of glucocorticoids upon testicular luteinizing hormone receptor and steroidogenesis in vivo and in vitro. Endocrinology 108 2142-2148

*Benediktsson R, Yau JLW, Low SC, Brett LP, Cooke BE, Edwards CRW and Seckl JR (1992) $11 \beta$-hydroxysteroid dehydrogenase in the rat ovary: high expression in the oocyte Journal of Endocrinology 135 53-58

Benediktsson R, Lindsay RS, Noble J, Seckl JR and Edwards CRW (1993) Glucocorticoid exposure in utero: new model for adult hypertension Lancet 341 339-341

*Bertram CE and Hanson MA (2002) Prenatal programming of postnatal endocrine responses by glucocorticoids Reproduction 124 459-467

Bertram CE, Trowern AR, Copin N, Jackson AA and Whorwood CB (2001) The maternal diet during pregnancy programmes altered expression of the GR and 11ßHSD2: potential molecular mechanisms underlying the programming of hypertension in utero. Endocrinology 142 2841-2853

Brotherton J (1990) Cortisol and transcortin in human seminal plasma and amniotic fluid as estimated by modern specific assays Andrologia 22 197-204

Brown RW, Chapman KE, Edwards CRW and Seckl JR (1993) Human placental $11 \beta$-hydroxysteroid dehydrogenase: evidence for and partial purification of a distinct NAD-dependent iosform Endocrinology 132 2614-2621

Burton PJ and Waddell BJ (1999) Dual function of $11 \beta$-hydroxysteroid dehydrogenase in placenta: modulating glucocorticoid passage and local steroid action Biology of Reproduction 60 234-240

Burton PJ and Waddell BJ (2002) Myometrial expression of $11 \beta$ hydroxysteroid dehydrogenase type 2 in rat pregnancy Journal of Endocrinology 172 519-526

Burton PJ, Dhamarajan AM, Hisheh S and Waddell BJ (1996a) Induction of myometrial 11ß-hydroxysteroid dehydrogenase type 1 messenger ribonucleic acid and protein expression in late pregnancy Endocrinology 137 5700-5706

Burton PJ, Smith RE, Krozowski ZS and Waddell BJ (1996b) Zonal distribution of $11 \beta$-hydroxysteroid dehydrogenase types 1 and 2 messenger ribonucleic acid expression in the rat placenta and decidua during late pregnancy Biology of Reproduction 55 1023-1028

Burton PJ, Krozowski ZS and Waddell BJ (1998) Immunolocalization of $11 \beta$-hydroxysteroid dehydrogenase types 1 and 2 in rat uterus: variation across the estrous cycle and regulation by estrogen and progesterone Endocrinology 139 376-382

Bush IE, Hunter SA and Meigs RA (1968) Metabolism of 11-oxygenated steroids Biochemical Journal 107 239-258

*Challis JRG, Matthews SG, Gibb W and Lye SJ (2000) Endocrine and paracrine regulation of birth at term and preterm Endocrine Reviews 21 514-550

Clarke KA, Ward JW, Forhead AJ, Giussani DA and Fowden AL (2002) Regulation of $11 \beta$-hydroxysteroid dehydrogenase type 2 activity in ovine placenta by fetal cortisol Journal of Endocrinology 172 527-534

Driver PM, Kilby MD, Bujalska I, Walker EA, Hewison M and Stewart PM (2001) Expression of $11 \beta$-hydroxysteroid dehydrogenase isozymes and corticosteroid hormone receptors in primary cultures of human trophoblast and placental bed biopsies Molecular Human Reproduction 7 357-363

Driver PM, Hewison M, Kilby MD and Stewart PM (2002) Oxygen tension regulates placental $11 \beta$-hydroxysteroid dehydrogenase type 2 Endocrine Abstracts 3 P221 (Abstract)

*Espey LL (1980) Ovulation as an inflammatory reaction - a hypothesis Biology of Reproduction 22 73-106

Evagelatou M, Peterson SL and Cooke BA (1997) Leukocytes modulate $11 \beta$-hydroxysteroid dehydrogenase (11 $\beta$-HSD) activity in human granulosa lutein cell cultures Molecular and Cellular Endocrinology 133 81-88

Fateh M, Ben-Rafael Z, Benadiva CA, Mastroianni L, Jr and Flickinger GL (1989) Cortisol levels in human follicular fluid Fertility and Sterility $\mathbf{5 1}$ 538-541

*Ferguson SE, Pallikaros Z, Michael AE and Cooke BA (1999) The effects of different culture media, glucose, pyridine nucleotides and adenosine on the activity of $11 \beta$-hydroxysteroid dehydrogenase in rat Leydig cells Molecular and Cellular Endocrinology 158 37-44

Ferrari P, Obeyesekere VR, Li K, Wilson RC, New MI, Funder JW and Krozowski ZS (1996) Point mutations abolish 11ß-hydroxysteroid dehydrogenase type II activity in three families with the congenital syndrome of apparent mineralocorticoid excess Molecular and Cellular Endocrinology 119 21-24

Funder JW, Pearce PT, Smith R and Smith AI (1988) Mineralocorticoid action: target tissue specificity is enzyme, not receptor, mediated Science 242 583-585

Gao H-B, Ge R-S, Lakshmi V, Marandici A and Hardy MP (1997) Hormonal regulation of oxidative and reductive activities of $11 \beta$-hydroxysteroid dehydrogenase in rat Leydig cells Endocrinology 138 156161

Gao H-B, Tong M-H, Hu Y-Q, Guo Q-S, Ge R-S and Hardy MP (2002) Glucocorticoid induces apoptosis in rat leydig cells Endocrinology 143 130-138

Ge R-S and Hardy MP (2000) Initial predominance of the oxidative activity of type $111 \beta$-hydroxysteroid dehydrogenase in primary rat Leydig cells and transfected cell lines Journal of Andrology 21 303-310

Ge R-S and Hardy MP (2002) Protein kinase C increases $11 \beta$-hydroxysteroid dehydrogenase oxidation and inhibits reduction in rat Leydig cells Journal of Andrology 23 135-143

Ge R-S, Hardy DO, Catterall JF and Hardy MP (1997a) Developmental changes in glucocorticoid receptor and $11 \beta$-hydroxysteroid dehydrogenase oxidative and reductive activities in rat Leydig cells Endocrinology 138 5089-5095

*Ge R-S, Gao H-B, Nacharaju VL, Gunsalus GL and Hardy MP (1997b) Identification of a kinetically distinct activity of $11 \beta$-hydroxysteroid dehydrogenase in rat Leydig cells Endocrinology 138 2435-2442

Goppelt-Struebe $\mathbf{M}$ (1997) Molecular mechanisms involved in the regulation of prostaglandin biosynthesis by glucocorticoids Biochemical Pharmacology 53 1389-1395

Hanafusa J, Mune T, Tanahashi T, Isomura $Y$, Suwa T, Isaji M, Daido $H$, Morita H, Murayama M and Yasuda K (2002) Altered corticosteroid metabolism differentially affects pituitary corticotropin response American Journal of Physiology - Endocrinology and Metabolism 282 E466E473

Hardy DB and Yang K (2002) The expression of 11ß-hydroxysteroid dehydrogenase type 2 is induced during trophoblast differentiation: effects of hypoxia Journal of Clinical Endocrinology and Metabolism 87 3696-3701

Hardy DB, Pereira LE and Yang K (1999) Prostaglandins and leukotriene B4 are potent inhibitors of $11 \beta$-hydroxysteroid dehydrogenase type 2 activity in human choricarcinoma JEG-3 cells Biology of Reproduction 61 40-45

Hardy DB, Dixon SJ, Narayan N and Yang K (2001) Calcium inhibits human placental $11 \beta$-hydroxysteroid dehydrogenase type 2 activity Biochemical and Biophysical Research Communications $283756-$ 761

*Hardy MP, Sottas CM, Ge R et al. (2002) Trends of reproductive hormones in male rats during psychosocial stress: role of glucocorticoid metabolism in behavioural dominance Biology of Reproduction 67 1750-1755

Harlow CR, Jenkins JM and Winston RML (1997) Increased follicular fluid total and free cortisol during the luteinizing hormone surge Fertility and Sterility 68 48-53

Harris HJ, Kotelevtsev Y, Mullins JJ, SeckI JR and Holmes MC (2001) Intracellular regeneration of glucocorticoids by $11 \beta$-hydroxysteroid dehydrogenase (11 $\beta-\mathrm{HSD})-1$ plays a key role in regulation of the hypothalamo-pituitary-adrenal axis: analysis of $11 \beta-H S D-1$-deficient mice Endocrinology 142 114-120 
*Hillier SG and Tetsuka M (1998) An anti-inflammatory role for glucocorticoids in the ovaries? Journal of Reproductive Immunology 39 $21-27$

Ho CK, Tetsuka M and Hillier SG (1999) Regulation of 11ß-hydroxysteroid dehydrogenase isoforms and glucocorticoid receptor gene expression in the rat uterus Journal of Endocrinology 163 425-431

Hsueh AJ and Erickson GF (1978) Glucocorticoid inhibition of FSH-induced estrogen production in cultured rat granulosa cells Steroids 32 639-648

Hundertmark S, Buhler H, Rudolf M, Weitzel HK and Ragosch V (1997) Inhibition of $11 \beta$-hydroxysteroid dehydrogenase activity enhances the antiproliferative effect of glucocorticosteroids on MCF-7 and ZR-75-1 breast cancer cells Journal of Endocrinology $\mathbf{1 5 5}$ 171-180

Jamieson A, Wallace AM, Andrew R, Nunez BS, Walker BR, Fraser R, White PC and Connell JMC (1999) Apparent cortisone reductase deficiency: a functional defect in 11ß-hydroxysteroid dehydrogenase type 1 Journal of Clinical Endocrinology and Metabolism 84 3570-3574

Jimena P, Castilla JA, Peran F, Ramirez JP, Vergara F, Jr, Molina R, Vergara F and Herruzo A (1992) Adrenal hormones in follicular fluid Acta Endocrinologica (Copenhagen) 127 403-406

Keay SD, Harlow CR, Wood PJ, Jenkins JM and Cahill DJ (2002) Higher cortisol:cortisone ratios in the preovulatory follicle of completely unstimulated IVF cycles indicate oocytes with increased pregnancy potential Human Reproduction 17 2410-2414

Kime DE, Scott AP and Canario AV (1992) In vitro biosynthesis of steroids, including 11-deoxycortisol and $5 \alpha$-pregnane-3 $\beta, 7 \alpha, 17,20 \beta$-tetrol, by ovaries of the goldfish Carassius auratus during the stage of oocyte final maturation General and Comparative Endocrinology 87 375-384

Klemcke HG and Christenson RK (1996) Porcine placental 11 $\beta$ hydroxysteroid dehydrogenase activity Biology of Reproduction 55 217223

Krozowski ZS and Funder JW (1983) Renal mineralocorticoid receptors and hippocampal corticosterone-binding species have identical intrinsic steroid specificity Proceedings National Academy of Sciences USA 80 6056-6060

Lakshmi V and Monder C (1988) Purification and characterization of the corticosteroid $11 \beta$-dehydrogenase component of the rat liver $11 \beta$ hydroxysteroid dehydrogenase complex Endocrinology 123 2390-2398

Lakshmi V, Nath N and Muneyyirci-Delale O (1993) Characterization of $11 \beta$-hydroxysteroid dehydrogenase of human placenta: evidence for the existence of two species of $11 \beta$-hydroxysteroid dehydrogenase Journal of Steroid Biochemistry and Molecular Biology 45 391-397

Leckie CM, Welberg LAM and SeckI JR (1998) 11ß-hydroxysteroid dehydrogenase is a predominant reductase in intact Leydig cells Journal of Endocrinology 159 233-238

Lesage J, Blondeau B, Grino M, Breant B and Dupouy JP (2001) Maternal undernutrition during late gestation induces fetal overexposure to glucocorticoids and intrauterine growth retardation, and disturbs the hypothalamo-pituitary adrenal axis in the newborn rat Endocrinology 142 1692-1702

Lopez-Bernal A, Flint APF, Anderson ABM and Turnbull AC (1980) $11 \beta$ hydroxysteroid dehydrogenase activity in human placenta and deciduas Journal of Steroid Biochemistry 13 1081-1087

Low SC, Chapman KE, Edwards CRW, Wells T, Robinson ICAF and SeckI JR (1994) Sexual dimorphism of hepatic $11 \beta$-hydroxysteroid dehydrogenase in the rat: the role of growth hormone patterns Journal of Endocrinology 143 541-548

McKenna TJ, Lorber D, Lacroix A and Rabin D (1979) Testicular activity in Cushing's disease Acta Endocrinologica (Copenhagen) 91 501-510

McTernan CL, Draper N, Nicholson H, Chalder SM, Driver P, Hewison M, Kilby MD and Stewart PM (2001) Reduced placental 11ßHSD2 mRNA levels in human pregnancies complicated by IUGR: analysis of possible mechanisms Journal of Clinical Endocrinology and Metabolism 89 4979-4983

Mercer WR and Krozowski ZS (1992) Localization of an 11ß-hydroxysteroid dehydrogenase activity to the distal nephron. Evidence for the existence of two species of dehydrogenase in the rat kidney Endocrinology 130 540-543

Michael AE, Pester LA, Curtis P, Shaw RW, Edwards CRW and Cooke BA (1993) Direct inhibition of ovarian steroidogenesis by cortisol and the modulatory role of $11 \beta$-hydroxysteroid dehydrogenase Clinical Endocrinology 38 641-644

*Michael AE, Gregory L, Piercy EC, Walker SM, Shaw RW and Cooke BA (1995) Ovarian 11ß-hydroxysteroid dehydrogenase activity is inversely related to the outcome of in vitro fertilization-embryo transfer treatment cycles Fertility and Sterility 64 590-598

*Michael AE, Evagelatou M, Norgate DP et al. (1997) Isoforms of $11 \beta$-hydroxysteroid dehydrogenase in human granulosa-lutein cells Molecular and Cellular Endocrinology 132 43-52

Michael AE, Collins TD, Norgate DP, Gregory L, Wood PJ and Cooke BA (1999) Relationship between ovarian cortisol:cortisone ratios and the clinical outcome of in vitro fertilization and embryo transfer (IVF-ET) Clinical Endocrinology 51 535-540

Monder C, Stewart PM, Lakshmi V, Valentino R, Burt D and Edwards CRW (1989) Liquorice inhibits corticosteroid 11 $\beta$-dehydrogenase of rat kidney and liver: in vivo and in vitro studies Endocrinology 125 1046-1053

*Monder C, Miroff Y, Marandici A and Hardy MP (1994) 11ßhydroxysteroid dehydrogenase alleviates glucocorticoid-mediated inhibition of steroidogenesis in rat Leydig cells Endocrinology 1341199 1204

Moore JS, Monson JP, Kaltsas G, Putignano P, Wood PJ, Sheppard MC, Besser GM, Taylor NF and Stewart PM (1999) Modulation of $11 \beta$-hydroxysteroid dehydrogenase isozymes by growth hormone and insulin-like growth factor: in vivo and in vitro studies Journal of Clinical Endocrinology and Metabolism 84 4172-4177

Morris DJ, Semafuko WEB, Latif SA, Vogel B, Grimes CA and Sheff MF (1992) Detection of glycyrrhetinic acid-like factors (GALFs) in human urine Hypertension 20 356-360

Mune T, Rogerson FM, Nikkila H, Agarwal AK and White PC (1995) Human hypertension caused by mutations in the kidney isozyme of 11ß-hydroxysteroid dehydrogenase Nature Genetics 10 394-399

Murdoch WJ, Wilken C and Young DA (1999) Sequence of apoptosis and inflammatory necrosis within the formative ovulatory site of sheep follicles Journal of Reproduction and Fertility 17 325-329

*Murphy BEP (1981) Ontogeny of cortisol-cortisone interconversion in human tissues: a role for cortisone in human fetal development Journal of Steroid Biochemistry 14 811-817

Murphy BEP, Clark SD, Donald IR, Pinsky M and Vedady DL (1974) Conversion of maternal cortisol to cortisone during placental transfer to the human fetus American Journal of Obstetrics and Gynaecology 118 538-541

*Nacharaju VL, Muneyyirci-Delale O and Khan N (1997) Presence of $11 \beta$ hydroxysteroid dehydrogenase in human semen: evidence of correlation with semen characteristics Steroids 62 311-314

Neumann A, Haider SG and Hilscher B (1993) Temporal coincidence of the appearance of elongated spermatids and of histochemical reaction of $11 \beta$-hydroxysteroid dehydrogenase in rat Leydig cells Andrologia $\mathbf{2 5}$ 263-269

Nikkila H, Tannin GM, New MI, Taylor NF, Kalaitzoglou G, Monder C and White PC (1993) Defects in the HSD11 gene encoding 11 $\beta$ hydroxysteroid dehydrogenase are not found in patients with apparent mineralocorticoid excess or 11-oxoreductase deficiency Journal of Clinical Endocrinology and Metabolism 77 687-691

Ono M and Oka T (1980) The differential actions of cortisol on the accumulation of $\alpha$-lactalbumin and casein in midpregnant mouse mammary gland in culture Cell 19 473-480

Osinski PA (1960) Steroid $11 \beta$-ol dehydrogenase in human placenta Nature 187777

*Patel FA, Sun K and Challis JRG (1999) Local modulation by $11 \beta$ hydroxysteroid dehydrogenase of glucocorticoid effects on the activity of 15-hydroxyprostaglandin dehydrogenase in human chorion and placental trophoblast cells Journal of Clinical Endocrinology and Metabolism 84 395-400

Penning TM (1997) Molecular endocrinology of hydroxysteroid dehydrogenases Endocrine Reviews 18 281-305

Pepe GJ, Waddell BJ, Stahl SJ and Albrecht ED (1988) The regulation of transplacental cortisol-cortisone metabolism by oestrogen in pregnant baboons Endocrinology 122 78-83 
Pepe GJ, Babischkin JS, Burch MMG, Leavitt MG and Albrecht ED (1996) Developmental increase in expression of the messenger ribonucleic acid and protein levels of $11 \beta$-hydroxysteroid dehydrogenase types 1 and 2 in the baboon placenta Endocrinology 137 5678-5684

Petrino TR, Lin YW, Netherton JC, Powell DH and Wallace RA (1993) Steroidogenesis in Fundulus heteroclitus V: purification, characterization, and metabolism of $17 \alpha, 20 \beta$,-dihydroxy-4-pregnen-3-one by intact follicles and its role in oocyte maturation General and Comparative Endocrinology 92 1-15

Phillipou G and Higgins BA (1985) A new defect in the peripheral conversion of cortisone to cortisol Journal of Steroid Biochemistry 22 435-436

Phillips DM, Lakshmi V and Monder C (1989) Corticosteroid 11 $\beta$ dehydrogenase in rat testis Endocrinology 125 209-216

Phillips ML and Schultz BD (2002) Steroids modulate transepithelial resistance and $\mathrm{Na}^{+}$absorption across cultured porcine vas deferens epithelia Biology of Reproduction 66 1016-1023

Pinter J and Thomas P (1999) Induction of ovulation of mature oocytes by the maturation-inducing steroid 17,20ß,21-trihydroxy-4-pregnen-3-one in the spotted seatrout General and Comparative Endocrinology 115 200-209

Pushkin A, Clark I, Kwon TH, Nielsen S and Kurtz I (2000) Immunolocalization of NBC3 and NHE3 in the rat epididymis: colocalization of NBC3 and the vacuolar $\mathrm{H}^{+}$-ATPase Journal of Andrology 21 708-720

Quirk SJ, Slattery JA and Funder JW (1990) Epithelial and adipose cells isolated from mammary glands of pregnant and lactating rats differ in 11ß-hydroxysteroid dehydrogenase activity Journal of Steroid Biochemistry and Molecular Biology 37 529-534

Rae MT, Niven D, Critchley HOD and Hillier SG (2003) Anti-inflammatory actions of cortisol on human ovarian surface epithelia (HOSE) cells Society for Gynecologic Investigation 50th Annual Scientific Meeting Abstract 674

Rastogi RK, Saxena PK and Iela L (1976) Histochemical localization of some hydroxysteroid dehydrogenases in the mouse epididymis Hormone Research 7 43-48

Ricketts ML, Verhaeg JM, Bujalska I, Howie AJ, Rainey WE and Stewart PM (1998) Immunohistochemical localisation of type $111 \beta$-hydroxysteroid dehydrogenase in human tissues Journal of Clinical Endocrinology and Metabolism 83 1325-1335

Sampath-Kumar R, Matthews SG and Yang K (1998) $11 \beta$-hydroxysteroid dehydrogenase type 2 is the predominant isozyme in the guinea pig placenta: decreases in messenger ribonucleic acid and activity at term Biology of Reproduction $\mathbf{5 9}$ 1378-1384

Sarkar S, Tsai S-W, Nguyen TT, Plevyak M, Padbury JF and Rubin LP (2001) Inhibition of placental $11 \beta$-hydroxysteroid dehydrogenase type 2 by catecholamines via $\alpha$-adrenergic signaling American Journal of Physiology (Regulatory and Integrative Comparative Physiology) 281 R1966-R1974

Schafers BA, Schlutius BG and Haider SG (2001) Ontogenesis of oxidative reaction of $17 \beta$-hydroxysteroid dehydrogenase and $11 \beta$-hydroxysteroid dehydrogenase in rat Leydig cells, a histochemical study Histochemical Journal 33 585-595

SeckI JR and Walker BR (2001) 11ß-hydroxysteroid dehydrogenase type 1 - a tissue-specific amplifier of glucocorticoid action Endocrino$\operatorname{logy} 142$ 1371-1376

Shams M, Kilby MD, Somerset DA, Howie AJ, Gupta A, Wood PJ, Afnan M and Stewart PM (1998) 11ß-hydroxysteroid dehydrogenase type 2 in human pregnancy and reduced expression in intrauterine growth restriction Human Reproduction 13 799-804

Smith MP, Mathur RS, Keay SD, Hall L, Hull MGR and Jenkins JM (2000) Periovulatory human oocytes, cumulus cells, and ovarian leukocytes express type 1 but not type $211 \beta$-hydroxysteroid dehydrogenase RNA Fertility and Sterility 73 825-830

Smith RE, Salamonsen LA, Komesaroff PA, Li KXZ, Myles KM, Lawrence M and Krozowski Z (1997) 11 $\beta$-hydroxysteroid dehydrogenase type II in the human endometrium: localization and activity during the menstrual cycle Journal of Clinical Endocrinology and Metabolism 82 4252-4257

Stewart PM, Wallace AM, Valentino R, Burt D, Shackleton $\mathrm{CH}$ and Edwards CRW (1987) Mineralocorticoid activity of liquorice: $11 \beta$-hydroxysteroid dehydrogenase deficiency comes of age Lancet 2 821-824
Stewart PM, Corrie JET, Shackleton CHL and Edwards CRW (1988) Syndrome of apparent mineralocorticoid excess. A defect in the cortisolcortisone shuttle Journal of Clinical Investigation 82 340-349

Stewart PM, Murry BA and Mason JI (1994) Type 2 11ß-hydroxysteroid dehydrogenase in human fetal tissues Journal of Clinical Endocrinology and Metabolism 78 1529-1532

Sun K, Yang K and Challis JRG (1997a) Differential expression of 11 $\beta$ hydroxysteroid dehydrogenase types 1 and 2 in human placenta and fetal membranes Journal of Clinical Endocrinology and Metabolism 82 300-305

Sun K, Yang K and Challis JRG (1997b) Differential regulation of $11 \beta-$ hydroxysteroid dehydrogenase type 1 and 2 by nitric oxide in cultured human placental trophoblast and chorionic cell preparation Endocrinology 138 4912-4920

*Sun K, Yang K and Challis JRG (1998) Regulation of $11 \beta$-hydroxysteroid dehydrogenase type 2 by progesterone, estrogen, and the cyclic adenosine $5^{\prime}$-monophosphate pathway in cultured human placental and chorionic trophoblasts Biology of Reproduction 58 1379-1384

Sun K, He P and Yang K (2002) Intracrine induction of $11 \beta$-hydroxysteroid dehydrogenase type 1 expression by glucocorticoid potentiates prostaglandin production in the human chorionic trophoblast Biology of Reproduction 67 1450-1455

Tannin GM, Agarwal AK, Monder C, New MI and White PC (1991) The human gene for $11 \beta$-hydroxysteroid dehydrogenase. Structure, tissue distribution and chromosomal localization Journal of Biological Chemistry 26616 653-16 658

Telleria CM, Ou J, Sugino N, Ferguson S and Gibori G (1998) The expression of interleukin- 6 in the pregnant rat corpus luteum and its regulation by progesterone and glucocorticoid Endocrinology 139 3597-3605

Terranova PF and Rice VM (1997) Review: cytokine involvement in ovarian processes American Journal of Reproductive Immunology 37 50-63

Tetsuka M, Thomas FJ, Thomas MJ, Anderson RA, Mason JI and Hillier SG (1997) Differential expression of messenger ribonucleic acids encoding $11 \beta$-hydroxysteroid dehydrogenase types 1 and 2 in human granulosa cells Journal of Clinical Endocrinology and Metabolism 82 2006-2009

*Tetsuka M, Milne M, Simpson GE and Hillier SG (1999a) Expression of $11 \beta$-hydroxysteroid dehydrogenase, glucocorticoid receptor, and mineralocorticoid receptor genes in rat ovary Biology of Reproduction $60330-335$

Tetsuka M, Haines LC, Milne M, Simpson GE and Hillier SG (1999b) Regulation of $11 \beta$-hydroxysteroid dehydrogenase type 1 gene expression by $\mathrm{LH}$ and interleukin-1 $\beta$ in cultured rat granulosa cells Journal of Endocrinology 163 417-423

Tetsuka M, Yamamoto S, Hayashida N, Hayashi KG, Hayashi M, Scosta TJ and Miyamoto A (2003) Expression of 11 $\beta$-hydroxysteroid dehydrogenase in bovine follicle and corpus luteum Journal of Endocrinology 177 445-452

Thomas FJ, Thomas MJ, Tetsuka M, Mason JI and Hillier SG (1998) Corticosteroid metabolism in human granulosa-lutein cells Clinical Endocrinology 48 509-513

Thompson A, Han VKM and Yang K (2002) Spatial and temporal patterns of expression of $11 \beta$-hydroxysteroid dehydrogenase types 1 and 2 messenger RNA and glucocorticoid receptor protein in the murine placenta and uterus during late pregnancy Biology of Reproduction $\mathbf{6 7}$ $1708-1718$

*Thurston LM, Norgate DP, Jonas KC, Chandras C, Kloosterboer HJ, Cooke BA and Michael AE (2002) Ovarian modulators of $11 \beta$-hydroxysteroid dehydrogenase $(11 \beta \mathrm{HSD})$ in follicular fluid from gonadotrophinstimulated assisted conception cycles Reproduction 124 801-812

Thurston LM, Fowkes RC, Burrin JM and Michael AE (2003a) $11 \beta$ hydroxysteroid dehydrogenase (11ßHSD) activities in $\alpha \mathrm{T} 3-1$ and $\mathrm{L} \beta \mathrm{T} 2$ gonadotroph cell lines: acute effects of $\mathrm{GnRH}$ and cAMP Reproduction Abstract Series $\mathbf{3 0}$ Abstract O8

Thurston LM, Michael AE, Jonas KC and Abayasekara DRE (2003b) $11 \beta$ hydroxysteroid dehydrogenase (11ßHSD) expression and activities in the developing ovarian follicle at defined phases of the bovine oestrus cycle Reproduction Abstract Series $\mathbf{3 0}$ Abstract O7

Thurston LM, Chin E, Jonas KC, Abayasekara DRE and Michael AE (2003C) Expression of $11 \beta$-hydroxysteroid dehydrogenase (11ßHSD) proteins in 
luteinizing human granulosa-lutein cells Journal of Endocrinology $\mathbf{1 7 8}$ 127-135

*Thurston LM, Norgate DP, Jonas KC, Gregory L, Wood PJ, Cooke BA and Michael AE (2003d) Ovarian modulators of type $111 \beta$-hydroxysteroid dehydrogenase (11ßHSD) activity and intra-follicular cortisol:cortisone ratios correlate with the clinical outcome of in vitro fertilization-embryo transfer (IVF-ET) Human Reproduction 18 1603-1612

Thurston LM, Jonas KC, Abayasekara DRE and Michael AE (2003e) Ovarian modulators of $11 \beta$-hydroxysteroid dehydrogenase (11ßHSD) activity in follicular fluid from bovine and porcine large antral follicles and spontaneous ovarian cysts Biology of Reproduction 68 2517-2163

Ulick S, Levine LS, Gunczler P, Zanconato G, Ramirez LC, Rauh W, Rosler A, Bradlow HL and New MI (1979) A syndrome of apparent mineralocorticoid excess associated with defects in the peripheral metabolism of cortisol Journal of Clinical Endocrinology and Metabolism 49 757-764

Waddell BJ and Burton PJ (2000) Full induction of rat myometrial $11 \beta$ hydroxysteroid dehydrogenase type 1 in late pregnancy is dependent on intrauterine occupancy Biology of Reproduction 62 1005-1009

Waddell BJ, Benediktsson R and SeckI JR (1996) 11ß-hydroxysteroid dehydrogenase type 2 in the rat corpus luteum: induction of messenger ribonucleic acid expression and bioactivity coincident with luteal regression Endocrinology 137 5386-5391

*Whittle WL, Patel FA, Alfaidy N, Holloway AC, Fraser M, Gyomorey S, Lye SJ, Gibb W and Challis JRG (2001) Glucocorticoid regulation of human and ovine parturition: the relationship between fetal hypothalamicpituitary-adrenal axis activation and intrauterine prostaglandin production Biology of Reproduction 64 1019-1034
Whorwood CB, Franklyn JA, Sheppard MC and Stewart PM (1992) Tissue localization of $11 \beta$-hydroxysteroid dehydrogenase and its relationship to the glucocorticoid receptor Journal of Steroid Biochemistry and Molecular Biology 41 21-28

Wu W-X, Derks JB and Nathanielsz PW (1996) Effects of glucocorticoids on estrogen receptor messenger ribonucleic acid in the pregnant ovine myometrium in vivo and in vitro. Biology of Reproduction $\mathbf{5 4}$ 230-241

Yang K (1995) Co-expression of two distinct isoforms of $11 \beta$-hydroxysteroid dehydrogenase in the ovine placenta Journal of Steroid Biochemistry and Molecular Biology 52 337-343

Yang K (1997) Placental 11ß-hydroxysteroid dehydrogenase: barrier to maternal glucocorticoid Reviews of Reproduction 2 129-132

Yang J-G, Chen W-Y and Li PS (1999) Effects of glucocorticoids on maturation of pig oocytes and their subsequent fertilizing capacity in vitro. Biology of Reproduction 60 929-936

Yang K, Fraser M, Yu M, Krkosek M, Challis JRG, Lamming GE, Campbell LE and Darnel A (1996) Pattern of 11ß-hydroxysteroid dehydrogenase type 1 messenger ribonucleic acid expression in the ovine uterus during the estrous cycle and pregnancy Biology of Reproduction 55 1231-1236

*Yong PYK, Thing KJ, Andrew R, Walker BR and Hillier SG (2000) Development-related increase in cortisol biosynthesis by human granulosa cells Journal of Clinical Endocrinology and Metabolism $\mathbf{8 5}$ 4728-4733

Yong PYK, Harlow C, Thong KJ and Hillier SG (2002) Regulation of $11 \beta$ hydroxysteroid dehydrogenase type 1 gene expression in human ovarian surface epithelial cells by interleukin-1 Human Reproduction 172300 2306 